\title{
Rękopisy i druki karaimskie w polskich zbiorach prywatnych. Nowe perspektywy badań karaimoznawczych*
}

\author{
Michał Németh \\ Uniwersytet Jagielloński w Krakowie, Wydział Filologiczny \\ Instytut Językoznawstwa
}

\section{Karaim manuscripts and old prints \\ in Polish private collections. \\ New perspectives in Karaim studies}

\begin{abstract}
Summary: This article presents the results of academic research conducted by a group of scholars in the years 2012-2016 on Karaim manuscripts owned by Polish individuals. The research was financed by the National Science Centre (Poland) (research project nr.: 2011/03/D/HS2/00618). The article provides a concise yet exhaustive description of the privately owned printed and handwritten materials and presents a great deal of hitherto unknown scientific data. The materials stored in private archives open up new perspectives on Karaim studies. They will undoubtedly serve as an important starting point for future research - primarily for historians and linguists, but also for those conducting literary, cultural, and religious studies.
\end{abstract}

Keywords: Karaim manuscripts, the history of Karaim, Karaim religious literature, Karaim cultural heritage

* Badania sfinansowano ze środków Narodowego Centrum Nauki przyznanych na podstawie decyzji numer 2011/03/D/HS2/00618 oraz 2015/17/B/HS2/01498. 


\section{Wprowadzenie}

Jakkolwiek w literaturze fachowej znajdziemy wiele informacji o drukach i starodrukach karaimskich, to jednak wiedza o istniejących rękopisach (nie tylko tych karaimskojęzycznych) jest znacznie trudniej dostępna, a szczególnie mało wiemy o rękopisach przechowywanych w zbiorach prywatnych. Źródła rękopiśmienne, z racji swej unikatowości, stanowią niezwykle ważne źródło poznania kultury, języka Karaimów, tym bardziej, że dorobek karaimskich oficyn wydawniczych czy znaczniejszych wydawców jest stosunkowo skromny. Rękopisy mają kardynalne znaczenie dla rozwoju szeroko pojętego karaimoznawstwa, a mimo to wciąż pozostają w znacznym stopniu niewykorzystane.

Treść druków karaimskich jest dobrze znana badaczom i nie są one już tak znaczącym motorem napędowym badań karaimoznawczych ${ }^{1}$. W wieku XX i XXI zostało opublikowanych kilka bibliografii obejmujących pozycje drukowane i rękopiśmienne w języku hebrajskim i karaimskim ze zbiorów przechowywanych w różnych instytucjach w Rosji, Wielkiej Brytanii, Niemczech, na Ukrainie czy w Izraelu. Wspomnieć w tym miejscu należy przede wszystkim o artykułach i monografiach Samuela Poznańskiego (artykuły wydane w latach 1909-1920), Jacoba Manna (1931), Davida Sklare’a (2003), Barry’ego Dova Walfisha (2003, 2010) oraz Olgi Vasilevej (2014). Większość odnotowanych w tych pracach pozycji to źródła powstałe w języku hebrajskim (głównie modlitewniki, prace filozoficzne czy księgi Tanachu), ale znajdziemy wśród nich również prace karaimskojęzyczne. W artykułach Tadeusza Kowalskiego (1929), Ananiasza Zajączkowskiego (1926, 1964) Henryka Jankowskiego (2009, 2012, 2013) czy Włodzimierza Zajączkowskiego (1980) znajdziemy opisy spuścizny piśmienniczej Karaimów zawierające także wzmianki o poszczególnych rękopisach przechowywanych w rodzinnych archiwach, jednak informacje bibliograficzne zostały w tych artykułach zamieszczone na marginesie rozważań naukowych, wzmianki o właścicielach lub miejscu przechowywania danego rękopisu lub druku są w tych starszych pracach nieaktualne, a artykuły Jankowskiego dotyczą wyłącznie dzieł krymskokaraimskich.

Przed drugą wojną światową Bernát Munkácsi (1909), Jan Grzegorzewski (1903, 1916-1918), Tadeusz Kowalski (1929, 1930) oraz Ananiasz Zajączkowski (1932, 1934, 1938) przedstawili łącznie ok. 100 utworów Karaimów polsko-litewskich.

1 Nie wliczając nielicznych, nadal trwających dyskusji, w tym np. tę nad językiem eupatoryjskiego druku Tanachu z 1841, ściśle powiązaną z kwestią odrębności języka Karaimów krymskich w klasyfikacji języków turkijskich, zob. np. Shapira (2003, 2013), Jankowski (2003a, 2003b), Németh (2015c, 2015d, 2015e, 2016a). 
Zważywszy jednak, że są to w zdecydowanej większości dzieła Karaimów z Litwy (w pracy Kowalskiego z 1929 roku znajdziemy ok. 90 takich pozycji), okazuje się, że zasoby polskich zbiorów prywatnych pozostały aż do początku drugiej dekady XXI wieku prawie całkiem nieznane (Karaimi litewscy, z różnych przyczyn, po drugiej wojnie światowej mieli znacznie bardziej utrudnioną drogę do Polski, niż objęci repatriacją Karaimi z terenów dzisiejszej Ukrainy) ${ }^{2}$. Tym bardziej, że od czasu zakończenia drugiej wojny światowej do 2012 roku (a więc do momentu rozpoczęcia pracy nad katalogiem rękopisów i druków, zob. niżej) opracowano lub wyedytowano niewiele ponad 20 rękopisów należących do tej grupy, zob. prace Włodzimierza Zajączkowskiego (1965), Józefa Sulimowicza (1972, 1973), Marioli Abkowicz (2007, 2008), Anny Sulimowicz (2008, 2010), Henryka Jankowskiego (2011) i Michała Németha (2009, 2010, 2011).

Wartość tych zbiorów jest tym większa, że w odróżnieniu od podobnych zbiorów znajdujących się za granicą (głównie w Rosji, na Litwie i Ukrainie oraz w Izraelu), w Polsce liczba tego typu zabytków przechowywanych w archiwach lub bibliotekach państwowych jest bardzo mała. Ich udział procentowy w liczbie wszystkich tego typu zabytków w Polsce, w porównaniu ze zbiorami prywatnymi, jest ułamkowy. Najwięcej bodaj pozycji przechowywanych jest w Archiwum Nauki PAN i PAU w Krakowie, przede wszystkim w zbiorach po profesorach Tadeuszu Kowalskim (1889-1948) i Janie Grzegorzewskim (ur. ok. 1846 lub 1849, zm. 1922) ${ }^{3}$. Znajdziemy tu przede wszystkim korespondencję Kowalskiego z Aleksandrem Mardkowiczem (1875-1944) i Sergiuszem Rudkowskim (1873-1944) ${ }^{4}$ oraz materiały językowe zebrane przez Grzegorzewskiego podczas jego wypraw naukowych do Karaimów z Halicza ${ }^{5}$. Tych materiałów jest jednak niewiele i są one w dużej mierze polskojęzyczne oraz rozproszone pod różnymi sygnaturami.

W literaturze fachowej dwukrotnie wspominano o polskich prywatnych zbiorach źródeł karaimskich: w dwóch publikacjach Aleksandra Dubińskiego

\footnotetext{
Zob. np. Pilecki (2012: 49-51).

O wątpliwościach związanych z datą narodzin Grzegorzewskiego zob. Dobosz (2012: 177-178).

$4 \quad$ O zbiorach Kowalskiego zob. np. Dziurzyńska (1999). Korespondencja Mardkowicza do Kowalskiego przechowywana jest w Archiwum Nauki PAN i PAU pod sygnaturą K III-4 j.a. 178; korespondencja Rudkowskiego do Kowalskiego znajduje się pod sygnaturą K III-4, j.a. 173. O korespondencji Kowalskiego i Mardkowicza zob. np. Dubiński (1988) czy Sulimowicz, A. (2013: 42 i n.).

5 O zbiorach karaimskich Grzegorzewskiego zob. Kowalski (1934), Kizilov (2013), Tyszkiewicz (2015).
} 
(1924-2002) z 1979 i 1985 roku. W artykule z 1985 roku autor stwierdza, że rękopisów karaimskich w rękach prywatnych jest ok. 150, a 75\% z nich znajduje się w Warszawie, w kolekcji płk. Józefa Sulimowicza (1913-1973), turkologa, od 1960 do 1972 roku dyrektora Centralnej Biblioteki Wojskowej (zob. Dubiński 1985: 8)6. Reszta, według Dubińskiego, miała się znajdować w archiwum ostatniego duchownego karaimskiego w powojennej Polsce, Rafała Abkowicza (1896-1992) we Wrocławiu ${ }^{7}$, oraz w jego, tj. Aleksandra Dubińskiego, rękach ${ }^{8}$. W tych dwóch przyczynkach brak jest jednak dokładnych informacji o zawartości tych zbiorów, a wspomniany przez Dubińskiego (1985: 24) plan stworzenia katalogu obejmującego wszystkie rękopiśmienne pozycje przechowywane w polskich zbiorach prywatnych ostatecznie nie został zrealizowany.

Z przeprowadzonego w latach 2007-2011 wstępnego rozeznania wynikało, że w kolekcji J. Sulimowicza rękopisów jest w rzeczywistości dużo więcej niż 150, a pojedyncze rękopisy znajdują się również w domach innych członków karaimskiej społeczności w Polsce?

\section{Katalog rękopisów i druków karaimskich}

Mając powyższe względy na uwadze, w 2012 roku, dzięki inicjatywie Marioli Abkowicz i Anny Sulimowicz, we współpracy z autorem niniejszego tekstu, uruchomiono prace nad zinwentaryzowaniem i skatalogowaniem rękopisów i druków karaimskich powstałych do 1989 roku i przechowywanych w polskich kolekcjach prywatnych. Wsparcie finansowe uzyskano od Narodowego Centrum Nauki (nr projektu: 2011/03/D/HS2/00618). Kierownikiem projektu był piszący te słowa.

W trakcie badań przeprowadzonych w latach 2012-2016 opisano łącznie ok. 460 pozycji. Rękopisy otrzymały między innymi szczegółowe spisy treści. Podjęto decyzję o stworzeniu serwisu internetowego zawierającego całe opisy katalogowe (zob. Németh \& Sulimowicz \& Abkowicz 2015). Karty katalogowe

6 O Józefie Sulimowiczu oraz o losach niektórych rękopisów z jego kolekcji zob. Dubiński (1973), Sulimowicz, A. (2013: 4-10; 2015a, 2015c: 176-178).

7 Więcej o nim zob. Abkowicz, R. (1999), Abkowicz, A. (2012).

8 Więcej o Aleksandrze Dubińskim zob. Kałużyński (1994), Csató (2002), Dubiński, Adam (2010). Warto w tym miejscu nadmienić, że cały księgozbiór Ananiasza Zajączkowskiego spłonął w sierpniu 1944 roku w wyniku bombardowania (Zajączkowska-Łopatto 2013: 13).

9 Nie wszyscy właściciele caraimików zgadzają się na upowszechnianie szczegółowych informacji o ich zbiorach. 
zawierają łącznie 30 rubryk (zob. Aneks). Mając na uwadze, że ustalenie podstawowych cech rękopisu, takich jak autorzy i tłumacze zawartych w nim utworów, tożsamość kopisty (lub kopistów), data i miejsce powstania manuskryptu czy afiliacja dialektalna danego tekstu karaimskiego, było najczęściej wynikiem długotrwałych badań, poniżej przedstawiono szczegółowy opis problemów związanych z poszczególnymi pozycjami opisu katalogowego.

\section{Autorzy opisu}

Są to, w kolejności alfabetycznej, wspomniani wyżej Mariola Abkowicz, Michał Németh, Anna Sulimowicz. W tej rubryce wyszczególniono te osoby, które brały udział w przygotowaniu opisu danej jednostki.

\section{Numer inwentarzowy}

Zgodnie z przyjętą na początku prac zasadą, rękopisy pozostawiono w miejscu ich pierwotnego przechowywania. Osoby, które przez kilka dziesiątków lat gromadziły i przechowywały rękopisy i druki wchodzące w skład badanych prywatnych kolekcji, umieszczały je na półkach swoich bibliotek zwykle według klucza tematycznego lub według źródła ich pochodzenia. Rękopisy będące darem innych rodzin karaimskich (o tym zob. np. Sulimowicz, A. 2015a: 170-171; 2015c: 177-178) zwykle pozostawiano razem, by ułatwić odtworzenie historii danych zabytków językowych oraz, oczywiście, by uszanować pamięć darczyńców. Miejsce przechowywania było więc nieraz pomocną poszlaką w ustalaniu proweniencji rękopisu, tzn. najczęściej dawało odpowiedź na pytanie, czy do Polski dotarły one z Halicza, Łucka, Trok, Wilna czy z Krymu (głównie z Teodozji). By zachować informatywną rolę miejsca przechowywania obiektów, w niektórych zbiorach regałom nadano numerację (numerami rzymskimi). Kolejny numer, cyframi arabskim, oznacza wolumin lub teczkę. Jeśli mamy do czynienia z teczką, po jej numerze następuje numer kolejny znajdującego się w niej rękopisu albo numer podteczki i tak dalej.

Numery inwentarzowe zostały wpisane do rękopisów i druków na wewnętrznych stronach okładek lub na pierwszych nadających się do tego kartach nieoprawionego lub uszkodzonego rękopisu. Wpisywano je miękkim ołówkiem (piszący te słowa korzystał z ołówków 6B i 8B).

\section{Tytul / Nazwa}

W tej rubryce zamieszczano tytuł danego druku lub rękopisu. Gdy dana pozycja nie nosiła tytułu, a działo się tak najczęściej w przypadku rękopisów, autorzy katalogu, dla przejrzystości, nadawali taką nazwę danej pozycji, która ją w prosty 
sposób charakteryzuje, jak np. Brudnopis listu, Fragment medżumy, Fragmenty modlitewnika, Hymny na święta doroczne, Miscellanea, Modlitewnik itp. Rękopisy były najczęściej nietytułowane z tej prostej przyczyny, że kopiści nie nadawali im tytułów. Ale pamiętać też należy, że to oprawa oraz początkowe i końcowe karty samego rękopisu były w pierwszej kolejności narażone na uszkodzenia fizyczne, więc w wielu przypadkach karty tytułowe po prostu się nie zachowały.

\section{Druk / Rękopis}

Pod tym względem skatalogowano cztery rodzaje jednostek: rękopisy, druki (w tym jeden druk hektograficzny z 1927), druki ze wstawkami rękopiśmiennymi oraz maszynopisy.

W większości przypadków rękopisy były dziełem jednego lub dwóch kopistów, wiele jest jednak jednostek składających się z kilku, połączonych ze sobą rękopisów (stanowiących w ten sposób spójną całość), będących pierwotnie dziełem różnych kopistów. Nierzadko zszyte w ten sposób rękopisy pochodziły z różnych okresów lub nawet z różnych gmin karaimskich (zob. niżej punkt 6), toteż tego typu pozycje wymagały szczególnej uwagi: ustalenie czasu, miejsca powstania, tożsamości kopisty itd. należało przeprowadzić dla każdej części osobno. W kolekcji znajdziemy również jeden tzw. klocek introligatorski zawierający teksty różnej treści i różnej proweniencji (głównie modlitwy, błogosławieństwa, hymny i elegie żałobne), w którym zszyte razem karty docięto do jednego rozmiaru bloku (chodzi o rkp. JSul.I.01).

Według pierwotnych założeń metodologicznych, maszynopisy miały nie wchodzić w skład katalogu, jednakże z racji ich ograniczonej liczby oraz zważywszy, że często były one przechowywane w teczkach wraz z rękopisami, postanowiono je również wciągnąć do katalogu.

Zinwentaryzowane druki to w głównej mierze siddury (książki modlitewne), a dokładniej modlitewnik wenecki (1528), modlitewnik z Kale (1737), dwa eupatoryjskie (z 1836 oraz z 1904 roku), wiedeński (1854), oraz wileński (1890-1892, oparty na siddurze wiedeńskim). Każdy z nich występuje w kilku, lub kilkunastu egzemplarzach. Ważnym drukiem jest również Tanach wydany w Eupatorii w 1841 roku - odnaleziono tylko dwa jego (czterotomowe) egzemplarze.

Druki ze wstawkami rękopiśmiennymi to w zdecydowanej większości przypadków modlitewniki z wszytymi między karty druku kartami zawierającymi różne uzupełnienia rękopiśmienne, jak np. uzupełnienie brakujących kart druku, przekłady na język karaimski modlitw wydrukowanych w języku hebrajskim lub dalsze modlitwy w języku hebrajskim i karaimskim, nieujęte w drukowanych modlitewnikach. 


\section{Obecność kart rękopiśmiennych}

Pozycja ta pozwala na sortowanie w bazie danych jednostek według obecności lub brak fragmentów rękopiśmiennych.

\section{Miejsce wydania / Miejsce powstania}

W przypadku druków ustalenie miejsca wydania nie sprawiało większego problemu. Jak już wcześniej wspomniano, druki karaimskie zostały w literaturze fachowej dobrze opisane, a karty tytułowe zawierają wszystkie potrzebne informacje. Było to możliwe nawet w przypadku druków zachowanych jedynie fragmentarycznie, bowiem na podstawie zawartości ocalałych kart, jakości papieru lub użytej do druku czcionki można stosunkowo łatwo ustalić, z którym drukiem mamy do czynienia. Znacznie trudniejsze było ustalenie miejsca powstania rękopisów.

Najważniejsze metody ustalania miejsca powstania rękopisu są dobrze znane filologom, a ich opis znajdziemy w opracowaniu historii każdego języka. Możemy być pewni miejsca powstania rękopisu, gdy zawarto tę informację w kolofonach (zwykle dołączanych do dłuższych partii przekładów utworów liturgicznych lub ksiąg Tanachu), we wpisach własnościowych (umieszczanych najczęściej na wewnętrznej stronie okładki czy oprawy, na kartach ochronnych lub w środku rękopisu - pomiędzy poszczególnymi rozdziałami lub utworami w zależności od rodzaju dzieła) lub w podpisie (np. w przypadku listów, okólników czy pism urzędowych). Kolofonów jest stosunkowo mało i powstawały zwykle w języku hebrajskim, choć zdarzają się tego typu adnotacje również w języku karaimskim, rosyjskim i polskim. Możemy być pewni miejsca powstania również tych rękopisów, w przypadku których znamy tożsamość autora autografu lub kopisty (zob. niżej punkty 8 i 12) i choćby przybliżoną datę powstania rękopisu. W sukurs przychodzi nam wówczas mikrohistoria gmin karaimskich oraz życiorysy poszczególnych osób ${ }^{10}$.

10 Ważnymi pracami w tej dziedzinie są monografie Manna (1931), Gąsiorowskiego (2008) lub Kizilova (2009b, 2015) lub słownik biograficzny Eĺjaševicza (1993). Jednak niekwestionowanymi ekspertami w tej dziedzinie są panie Mariola Abkowicz oraz Anna Sulimowicz. Ich znajomość historii gmin karaimskich i historii rodzin zamieszkujących te gminy obejmuje XX, XIX i częściowo XVIII a nawet XVII wiek. Dane historyczne i biograficzne czerpią one z różnych źródeł: przede wszystkim ksiąg metrykalnych i spisów ludności, a także z rękopisów (np. modlitw za zmarłych) i notatek z wywiadów z przedstawicielami starszych pokoleń. Godne uwagi są ich badania historyczne oparte na analizach setek fotografii przechowywanych w zbiorach rodzinnych (Abkowicz \& Sulimowicz 2010). Pozostaje mi w tym miejscu 
Sprawa komplikuje się, gdy nie znamy autora lub kopisty. Wówczas kierować się można wskazówkami paleograficznymi, takimi jak na przykład dukt pisma kopisty, kształt liter, właściwości papieru (zob. dalsze szczegóły w punktach 12,18 i 21). W nielicznych przypadkach pomocne są znaki papierni, bowiem papieru z rosyjskich papierni nie używano w Haliczu (zabór austriacki). Charakterystyczny ślad pozostawia tzw. surałar, tj. narzędzie używane do wytłaczania liniowania w papierze, a ponieważ posługiwano się nim wyłącznie w Haliczu, jego użycie również służyć może jako wskazówka przy ustalaniu miejsca powstania rękopisu'11. Kolejną ważną wskazówką jest sam język utworu, choć tu już należy być ostrożnym w świetle częstych migracji Karaimów do odległych gmin, zwłaszcza gdy dotyczy to duchownych ${ }^{12}$, gdyż to oni najczęściej sporządzali kopie tekstów związanych z praktyką religijną (więcej na ten temat w punkcie 14). Ciekawym zjawiskiem opisanym przez Kowalskiego (1929: xix, 289) jest wokalizowanie (zob. punkt 19) tekstów północnozachodnich zgodnie z fonologią dialektu południowozachodniego: działo się tak z pierwotnie niewokalizowanymi tekstami północnozachodnimi powstałymi w Kukizowie, które po upadku gminy w latach 30. XIX wieku trafiły wraz z ich właścicielami do Halicza. Bazując na tej wiedzy, możemy założyć, że część rękopisu JSul.I.01 pochodzi z Kukizowa (zob. kk. $125 \mathrm{r}^{\mathrm{o}}-125 \mathrm{v}^{\mathrm{o}}$; o rękopisie tym była mowa wyżej) i została w wyżej wspomnianym czasie przewieziona do Halicza.

W przypadku wielu obiektów nie można było ze stuprocentową pewnością określić miejsca ich powstania. Wówczas w tej rubryce wpisywano kwalifikator Niepodane lub wpisywano prawdopodobne miejsce powstania manuskryptu ze znakiem zapytania w nawiasie.

wyrazić nadzieję, że w przyszłości powstanie słownik biograficzny ich autorstwa, zawierający syntezę informacji zdobywanych przez ostatnie kilkanaście lat, a w chwili obecnej mocno rozproszonych.

11 Zob. Sulimowicz, J. (1968).

12 Oto nazwiska kilku osobistości, które pełniły funkcję duchownych nie w swoich rodzinnych stronach: Józef Szełomo Łucki, zwany Jaszar (1768 (1770?) - 1855; ur. w Łucku, zm. w Eupatorii), Mordechaj Sułtański (1772-1862; ur. w Łucku, od 1811 aż do śmierci mieszkał na Krymie), Abraham Firkowicz (1786-1874; ur. w Łucku, od lat 30. XX w. związany z Krymem), Jeszua Josef Mordkowicz (1802-1884; ur. w Kukizowie, po upadku gminy przeniósł się do Halicza, od 1866 hazzan w Haliczu), Józef Łobanos (1880-1947; ur. w Wilnie, w latach 1938-1939 hazzan w Łucku, zm. w Wilnie), Rafał Abkowicz (1896-1992; ur. w Trokach, w latach 1929-1938 hazzan w Łucku, od 1938 roku hazzan w Wilnie, od 1946 hazzan we Wrocławiu; zm. we Wrocławiu). 
W badanych zbiorach odnaleziono jednostki powstałe w następujących miejscowościach ${ }^{13}$ : Halicz (a także: Halicz lub Łuck), Kukizów, Łuck (w tym Krasne, obecnie dzielnica Łucka), Troki, Wilno (a także: Troki lub Wilno), Poniewież, Powiat upicki, Poswol, Szawle, Nowe Miasto, Malowanka, Litwa (sformułowanie ogólne wobec braku bardziej dokładnych danych), Kale, Eupatoria (kar. Gözleve), Symferopol, Sewastopol (?), Krym (sformułowanie ogólne wobec braku bardziej dokładnych danych), Petersburg, Odessa, Mikołajów, Berdyczów, Wrocław, Gdańsk (Gdańsk Oliwa), Kraków.

\section{Data wydania / Data powstania}

Ustalenie daty wydania druków, ze względów wymienionych w punkcie 6, najczęściej nie sprawia większych problemów. Znacznie trudniejsze jest ustalenie dat powstania tych rękopisów, w których data ta nie została jednoznacznie zapisana. Ustalenie momentu powstania listów, okólników lub pism urzędowych jest zwykle najprostsze (najczęściej zawierają miejsce i datę ich napisania oraz podpis autora), ale tego typu pism jest najmniej (zob. edycję ok. dwudziestu tego typu dokumentów w Németh 2010; 2011b; 2012, 2013a; 2013b; Sulimowicz 2014; 2015c). Nierzadko datę kopiowania znajdziemy w hebrajskim nagłówku do któregoś z utworów skopiowanych w rękopisie. Daty te zwykle nie są eksponowane czy powtarzane na wewnętrznych kartach oprawy czy kartach tytułowych. Kolofony zdarzają się stosunkowo rzadko, a daty w nich wyrażano według powszechnie znanego systemu i najczęściej według skróconej rachuby czasu. W nielicznych przypadkach datę ukrywano pod wartością liczbową hebrajskich liter składających się np. na cytat biblijny. Np. w rękopisie Pięcioksięgu oznaczonym numerem inwentarzowym ADub.III.73, datę powstania rękopisu wyrażono hebrajskim sformułowaniem ודלעת (trzy kropki, a dokładniej znak kantylacyjny segol, nad literą ajin sygnalizuje, że mamy tu do czynienia z abrewiaturą lub wyrażeniem daty), a więc hebr. וְדַעַת 'i umiejętność; i znajomość', czyli cytatem z Księgi

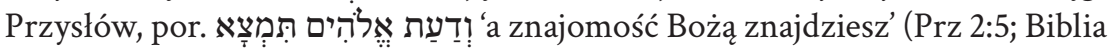

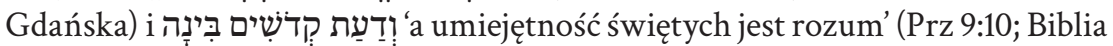
Gdańska). Chodzi o rok 5480 A.M., czyli rok 1720 A.D. ${ }^{14}$. Najczęściej jednak

13 Wyszczególnione są one w tym miejscu wg częstotliwości występowania (w kolejności od najczęstszych do tych najrzadszych). Miejscowości, które pojawiają się bardzo rzadko (praktycznie dotyczy to prawie wszystkich miejscowości z wyjątkiem Halicza, Łucka, Kukizowa, Trok oraz Wilna) uszeregowano podług klucza geograficznego.

14 Kolofon zawiera dokładną datę kopiowania: pracę nad nim zaczęto dnia 15 miesiąca adar szeni a zakończono 23 dnia miesiąca ijar, chodzi więc o rok 1720 A.D. Dzięki tej 
brak jest jednoznacznie wyrażonej daty i wówczas należy dokładnie przeczytać cały rękopis w celu odnalezienia dodatkowych wskazówek. I tak np. w rkp. JSul.III.02 zawierającym przekład Proroków Dawniejszych (tj. ksiąg Jozuego, Sędziów, Samuela I i II, i Królów I i II), Księgi Rut, Księgi Estery i fragment Księgi Przysłów na język Karaimów krymskich znajdziemy kolofon, w którym nabywca (niejaki Szełomo ha-Maskil) stwierdza, iż książkę nabył w roku 5453 A.M., tj. 1692/1693 A.D., od spadkobierców kopisty Abrahama ben Szemoela. Data nabycia rękopisu stanowi więc terminus ad quem powstania rękopisu. Jednak datę tę można jeszcze bardziej uściślić, gdyż rękopis ten zawiera również listę sułtanów panujących „w Bursie i Konstantynopolu” sporządzoną w języku hebrajskim i obejmującą lata 1299-1774, a ostatni wpis ręką kopisty przekładów ksiąg biblijnych kończy się na dacie intronizacji Sulejmana II (1687). Co więcej, owego ostatniego wpisu dokonano całkiem innym atramentem i piórem niż wszystkie inne wpisy, a więc te obejmujących lata 1299-1648 aż do intronizacji Mehmeda IV (data panowania: 1648-1687) oraz tekst główny rękopisu - tekst główny i wspomniane wpisy Abraham ben Szemoel sporządził tym samym piórem, takim samym atramentem i z taką samą interlinią. Z powyższego możemy więc wnioskować, że według wszelkiego prawdopodobieństwa rękopis powstał przed 1687 rokiem, jednak nie wcześniej niż $1648^{15}$.

Powróćmy jednak jeszcze do wspomnianych wyżej nagłówków. Ustalenie daty powstania bardzo często opierano na ich analizie porównawczej. Nagłówki te wprowadzają różnego rodzaju utwory liturgiczne (o tym zob. punkt 13) i w nielicznych przypadkach mogą zawierać np. datę kopiowania tekstu lub datę dokonania przekładu kopiowanego utworu. Ich główną rolą było jednak podanie informacji o tym, z jakiego rodzaju utworem mamy do czynienia, przy jakiej okazji powinien on być czytany oraz o tym, kim był jego autor lub tłumacz. Tak więc nagłówki te bardzo często zawierają imiona (najczęściej analityczne patronimy z hebrajskim ben 'syn'), mówiąc ściślej, hieratyczne struktury oznaczeń osobowych, w których oprócz imion syna i ojca podawano wszelkie znane ich tytuły (tak syna, jak i ojca lub dalszych przodków) w towarzystwie licznych zwrotów grzecznościowych. Wymienienie w nagłówku osoby, której życiorys jest choćby częściowo odtworzony, daje wiele możliwości dalszych badań.

dacie wiemy, że rękopis ten zawiera najstarszy znany nam przekład Tory na język Karaimów zachodnich. Szerzej o tym rękopisie zob. Németh (2014d; 2015c; 2015d).

15 Dzięki tej dacie z kolei wiemy, że rękopis JSul.III.02 zawiera najstarsze znane przekłady biblijne na język krymskokaraimski. Więcej o tym rękopisie zob. Németh (2016a). 
Na przykład imionom osób nieżyjących w momencie tworzenia rękopisu zawsze towarzyszą określenia odpowiadające polskim zwrotom błogosławionej pamięci czy świętej pamięci, toteż w przypadku, gdy jesteśmy w stanie ustalić tożsamość osoby wspomnianej w nagłówku i znamy datę jej śmierci, data ta służyć może jako terminus post quem powstania rękopisu' ${ }^{16}$. Mutatis mutandis, przy ustalaniu chronologii względnej powstania rękopisu równie pomocną informacją jest odnalezienie wzmianki o takiej osobie żyjącej w momencie kopiowania tekstu, której daty narodzin i śmierci są znane ${ }^{17}$. Nagłówki są więc nie tylko źródłem wiedzy o poszczególnych osobach i ich związkach genealogicznych z innymi osobami wymienionymi w manuskryptach, ale również o dacie powstania rękopisu.

Gdy nie jesteśmy w stanie ustalić wieku rękopisu na podstawie jego treści, należy sięgnąć po metody niefilologiczne. Pomocnym może być wszelka wskazówka historyczna lub paleograficzna - tj. kształt liter, kształt liter kaligrafowanych, grubość końcówki pióra, kolor atramentu, użycie stalówki czy właściwości papieru (czerpany czy maszynowy). W przypadku, gdy rękopis datowano wyłącznie na podstawie wskazówek paleograficznych, wiek rękopisu podawano opisowo, przyporządkowując go najczęściej do 1 lub 2 połowy wieku XVIII, XIX lub XX.

16 Wspomniane zwroty były prawie zawsze zapisywane w postaci abrewiatur. Najczęstsze zwroty z tej grupy to (znak kantylacyjny zarqa służy dla oznaczenia abre-

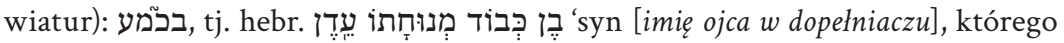

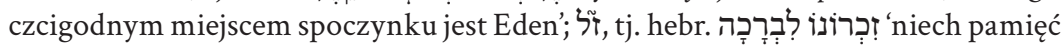

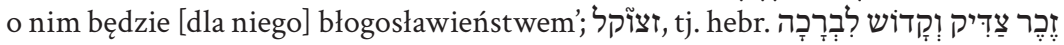
'niech pamięć o sprawiedliwym i świętym będzie [dla niego] blogosławieństwem';

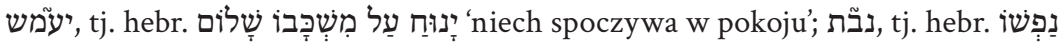

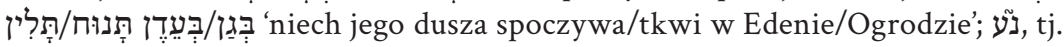

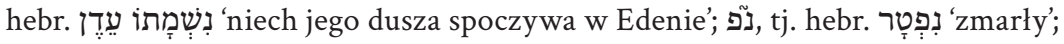

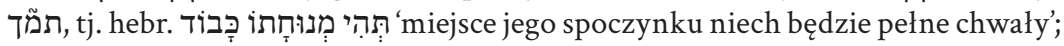

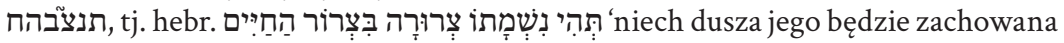

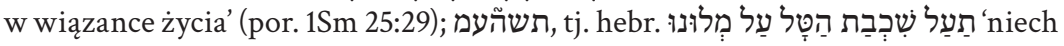
rosa ukaże się na miejscu jego spoczynku' (por. Wj 16:13-14).

17 Gdy po imieniu takiej osoby nie występuje żaden zwrot wskazujący na to, iż osoba ta nie żyje, możemy z dużą dozą prawdopodobieństwa założyć, że osoba żyła w czasie sporządzania rękopisu. Wymienione w poprzednim przypisie sformułowania były bowiem używane dość konsekwentnie. Istnieje jednak kilka sformułowań, których

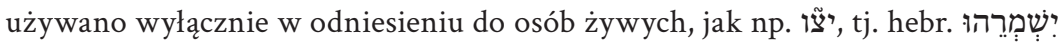

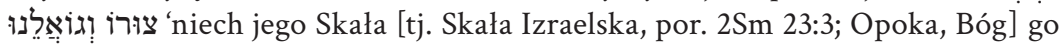
zachowa'. Tego typu sformułowań jest jednak znacznie mniej, a ich użycie nie było konsekwentne. 
Ogólnie rzecz ujmując, w przebadanych zbiorach znajdziemy karaimskie rękopisy od XVII do XX wieku oraz druki od XVI do XX wieku. Zdecydowana większość zachowanego piśmiennictwa powstała w czasach późniejszych, głównie w XIX i XX wieku. Jednak wartość tych mniej licznych starszych rękopisów jest nie do przecenienia.

\section{Autor}

Autorzy utworów zawartych w drukach są często nieznani; z oczywistych względów niemożliwym jest ustalenie autorów modlitw czy ksiąg biblijnych. Gdy zaś autor druku jest znany, informacja ta jest łatwa do uzupełnienia na podstawie kart tytułowych. Takich prac jest jednak bardzo niewiele, bowiem większość druków autorskich powstało w XX wieku (przede wszystkim w okresie międzywojennym) i z racji faktu, że są one powszechnie znane, latwo dostępne i dobrze opisane nie zostały one wciągnięte do katalogu rękopisów i druków starych ${ }^{18}$.

W przypadku rękopisów autorskich w rubryce Autor wpisane zostało imię autora rękopisu, jeśli jest ono znane, a rubrykę Kopista skreślano ${ }^{19}$. W przypadku źródeł innych niż autografy rubrykę tę uzupełniano na kilka sposobów. Jeśli dany rękopis zawierał utwory niebędące autorstwem jednej osoby, nie wpisywano do tej rubryki wszystkich zidentyfikowanych autorów. Niektóre rękopisy zawierały bowiem dzieła autorstwa kilkunastu lub kilkudziesięciu osób, przy czym w większości rękopisów znajdziemy również utwory, których autorzy są nieznani lub ich imiona nie zostały podane w żadnym $\mathrm{z}$ analizowanych rękopisów. W takim przypadku do tej rubryki wpisywano Zob. Informacja o treści (zob. niżej punkt 13), tam zaś do każdego utworu wyszczególnionego w spisie treści przyporządkowano imię autora. Jeśli rękopis zawierał tylko takie utwory, których autorzy są nieznani, w rubryce Autor odnotowano Niepodany lub Niepodani. Jeśli zaś rękopis zawierał utwory autorstwa jednej i tej samej osoby, jej imię odnotowano w tej rubryce. Podobnie postąpiono odnośnie do tłumaczy utworów zawartych w jednym rękopisie.

Tożsamość autora została przez kopistów w zdecydowanej liczbie przypadków umieszczona w hebrajskich nagłówkach wprowadzających dany utwór, rzadziej w kolofonach. Gdy kopista kopiował kilka utworów danego autora jeden za drugim, w nagłówkach najczęściej nie powtarzał jego (pełnego) imienia, ale odsyłał czytelnika do nagłówka pierwszego skopiowanego utworu tego autora, pisząc, że autorem danego dzieła jest „wyżej wspomniany” - kopista używał w tej sytuacji

18 Druki międzywojenne ujęte zostały w Abkowicz \& Sulimowicz \& Kameduła (2015).

19 Nota bene autografy to zwykle źródła młodsze, z późnego XIX lub z XX wieku. 


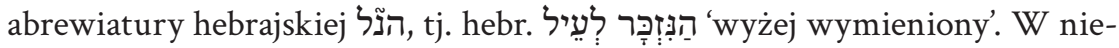
licznych przypadkach, gdy autorem danego utworu był członek rodziny kopisty, zamiast podania pełnego imienia autora, korzystał on z odesłań genealogicznych, pisząc na przykład, iż autorem tekstu był jego brat, zięć czy teść. Wówczas, chcąc ustalić tożsamość autora, należało wprzódy ustalić tożsamość kopisty.

Dzięki przeprowadzonym badaniom i analizom porównawczym zawartości dostępnych w archiwach rękopisów udało się ustalić lub potwierdzić autorstwo przeszło 80 hymnów i pieśni liturgicznych.

\section{Tłumacz}

Druków zawierających tłumaczenia jest niewiele. W kartach katalogowych rękopisów tłumaczy poszczególnych utworów opisano podobnie jak ich autorów.

Imiona osób dokonujących przekładu danego utworu, podobnie jak w przypadku autorów tych dzieł, kopista zwykle wymieniał w nagłówkach wprowadzających dane tłumaczenie. Jeśli chodzi o praktyki podawania tych informacji przez kopistów, nie różnią się one od tego, co zostało opisane w punkcie poświęconym autorom (punkt 8).

Większość tłumaczeń to tzw. peszaty z języka hebrajskiego, a więc interpretacje tekstu oryginalnego, zwykle znacznie dłuższe niż oryginał. Znajdziemy jednak również tłumaczenia we współczesnym tego słowa znaczeniu. Innych przekładów niż tych z języka hebrajskiego na język karaimski jest niezwykle mało. Wymienić tu należy:

- przekład pieśni XXV Jana Kochanowskiego Czego chcesz od nas Panie (tłumaczem był Zarach z Trok syn Natana (1578-1657/1658); incipit przekładu karaimskiego: Ne klajśeń biźd’an Teńrim);

- przekład pieśni religijnej z języka polskiego na język karaimski (tłumacz: Zarach z Trok syn Natana; incipit przekładu karaimskiego: Téńrim keldi tas bolma);

- przekład Roty Marii Konopnickiej na język karaimski (tłumacz: Leon Eszwowicz (1887-1947); tłumaczenie powstało w latach 20. XX wieku; incipit przekładu karaimskiego: Taslamabiz ol jerni ${ }^{20}$;

- przekład Psalmu 91 z języka polskiego (nie hebrajskiego!) na język karaimski (tłumacz: Szełomo syn Aharona z Poswola, autor dzieła Appirion; (1670?-1745); incipit karaimskiego przekładu: Kim symarlansa);

20 Zob. Sulimowicz, A. (2015c); w artykule tym znajdziemy również listę innych utworów polskich przełożonych na język karaimski, zob. str. 101-103. 
- nieliczne przekłady tekstów świeckich z języka polskiego na język hebrajski w rkp. RAbk.IV.0321;

- przekład z języka karaimskiego na język polski karaimskiej pieśni religijnej (tzw. zemeru) autorstwa hazzana Josefa syna Jeszui z Derażna zaczynającej się od słów Tenrim ker ki tištiler jizlerim (tłumacz niepodany; incipit polskiego przekładu: Zwidź Panie Boże na moje zalżywości);

- przekład z języka karaimskiego na język polski modlitwy autorstwa hazzana Rafała Abkowicza (1896-1992) zaczynającej się od słów Ḱućlu Teńríśi ol Teńrílaŕnín (tłumacz: Natalia Abkowicz; incipit polskiego przekładu: Wszechmogacy Pan nad panami);

- przekład z języka karaimskiego na język hebrajski zemeru autorstwa wspomnianego wyżej Szełomo syna Aharona z Poswola zaczynającego się od słów Küčlü bijim kipligim (tłumacz nieznany);

- przekład z języka karaimskiego na język hebrajski zemeru autorstwa Josefa ha-Maszbira syna Szemoela z rodu ha-Rodi (zm. ok. 1700) zaczynającego się od słów Aziz zan ojanhyn kiple belinni (tłumacz: Mordechaj syn Nisana z Trok; przypuszczalnie chodzi o Mordechaja syna Nisana Łokszyńskiego, zm. prawdopodobnie w 1710 r.);

- przekłady z języka karaimskiego (dial. krymski) na język rosyjski siedmiu utworów świeckich (teksty folklorystyczne, anegdoty, powiedzenia; tłumacz: Josif Kefeli) oraz

- kilka przekładów listów, sprawozdań itp. na język rosyjski.

W wyniku badań porównawczych zawartości rękopisów ustalono lub potwierdzono tożsamość tłumaczy przeszło 100 przekładów hymnów i pieśni liturgicznych.

\section{Io. Wydawca}

Kategoria ta z przyczyn oczywistych dotyczy wyłącznie druków. Informację o wydawcy znajdziemy na kartach tytułowych.

\section{Drukarnia}

Kategoria ta dotyczy oczywiście druków. Informację o drukarni znajdziemy na kartach tytułowych.

21 Ta część rękopisu została wydana krytycznie przez Piotra Muchowskiego (2013a). 


\section{Kopista}

W ustaleniu osoby kopisty pomocne są z jednej strony kolofony, w których jego imię bywało wymieniane expressis verbis oraz, z drugiej strony, wspomniane już hebrajskojęzyczne nagłówki wprowadzające poszczególne utwory. Bazując na tych ostatnich, tożsamość kopisty możemy ustalić najczęściej na podstawie odesłań genealogicznych (podobnie jak w przypadku autorów lub tłumaczy, zob. punkt 8). Często spotykane są również sformułowania typu „utwór mojego autorstwa”, „przetłumaczyłem to ja”, gdy kopista był zarazem autorem lub tłumaczem danego utworu; w takich przypadkach kopista najczęściej podawał również swoje imię (często w pełnej postaci).

Tożsamość nielicznych kopistów można również ustalić na podstawie ich duktu pisma lub stosowanych przez nich znaków pisarskich. Na przykład bardzo charakterystyczne i łatwe do rozpoznania jest pismo jednego z najbardziej aktywnych kopistów XIX wieku, Jeszui Josefa Mordkowicza (1802-1884) z Halicza ${ }^{22}$.

Tożsamości kopisty bardzo często nie udało się ustalić. Zdradzanie swojej tożsamości przez kopistów stało się bardziej powszechne dopiero od drugiej połowy XIX wieku.

\section{Informacja o treści}

W tej rubryce umieszczano ogólny i szczegółowy opis zawartości danego rękopisu. Opis szczegółowy zawiera numery strony lub karty, na której dany utwór został zapisany, więc można go traktować jako klasyczny spis treści.

Ponieważ druki karaimskie, jak już wcześniej wspominano, zostały dobrze opisane, zrezygnowano w powtarzania szeroko dostępnych informacji. Druki uzyskały więc opis bardziej ogólny, często uzupełniony przez odsyłacze do literatury fachowej.

Jeśli chodzi o zawartość rękopisów lub wstawek rękopiśmiennych umieszczonych w drukach, znacznie bardziej szczegółowo opisano fragmenty karaimskojęzyczne, bowiem sam projekt badawczy miał z założenia koncentrować się na tych źródłach. Pamiętać należy, że język karaimski jest językiem częściowo wymarłym, społeczność karaimska bardzo nieliczna, a o liturgii

22 Jest ono łatwe do zidentyfikowania mimo pewnej różnicy między kształtem liter stawianych przez niego w okresie jego młodości i tych z ostatnich lat jego działalności. Nota bene to w jego warsztacie powstała kopia fragmentów Tanachu częściowo opracowana przez Zsuzsannę Olach (2013). W pracy Olach nie podjęto jednak próby zidentyfikowania kopisty. 
karaimskojęzycznej z XVIII-XIX wieku oraz o przekładach Tanachu wiedzieliśmy dotychczas niewiele - w odróżnieniu od źródeł hebrajskojęzycznych. Toteż każdy jeden utwór napisany językiem karaimskim został scharakteryzowany następująco: ustalono jego gatunek literacki, podano jego incipit (w oryginale i w transkrypcji), podjęto próbę ustalenia jego autora oraz w przypadku przekładów również tłumacza, ustalono przynależność dialektalną zawartości językowej oraz, gdy dany tekst ma duże znaczenie naukowe, w osobnych uwagach umieszczano wzmianki dotyczące jego unikatowości (są to spostrzeżenia ważne przede wszystkim dla językoznawców zajmujących się językoznawstwem historycznym i historyków). Z tych ostatnich uwag czytelnik dowie się również, które teksty są niewokalizowane (zob. punkt 19).

Jeśli chodzi o gatunki literackie i rodzaje opisanych tekstów, to w rękopisach znajdziemy przede wszystkim utwory religijne (tłumaczenia biblijne, teksty liturgiczne i paraliturgiczne). Są to w przeważającej mierze: modlitwy błagalne (bakkeszot, kar. bakkesza; tachanunim, kar. tachanun) ${ }^{23}$, pokutne (selichot, kar. selicha), konfesyjne (viddujim, kar. vidduj), modlitwy wieczorne i poranne, modlitwy na dni powszednie, na dni sobotnie, na dni świąteczne, modlitwy wstępne, pieśni religijne (pijjutim, kar. pijjut; szirim, kar. szira), hymny religijne (zemirot, kar. zemer), błogosławieństwa (berachot, kar. beracha), elegie żałobne (kinot, kar. kyna), mowy pogrzebowe i kazania (deraszot, kar. derasza), utwory religijne o ofiarowaniu Izaaka (akidot, kar. akyda), pieśni na święto Purim (kar. ahavat), tzw. Hagada, pieśni recytowane o świcie, przekłady ksiąg Starego Testamentu, Haftara oraz pieśni okolicznościowe (np. pieśni recytowane przy stole w domu pana młodego w sobotę poprzedzającą ślub, pieśni czytane podczas uroczystości weselnych, pieśni na uroczystość obrzezania, pieśni o treści dydaktycznej itp.). Poza tym w rękopisach znajdziemy teksty świeckie, takie jak teksty folklorystyczne czy utwory ludowe (pieśni, powiedzenia, mądrości ludowe, zagadki ludowe zawarte najczęściej w tzw. medżumach itp.), teksty kabalistyczne, listy prywatne, okólniki, dokumenty, wykazy (np. wykazy narodzin, zaślubin, zgonów), wpisy o narodzinach lub śmierci członków rodzin i in.

23 Hebrajskie nazwy używane przez Karaimów, zgodnie z tradycją hebraistyczną, podaję w hebrajskiej liczbie mnogiej i w ortografii polskiej. Po niej zamieszczam karaimską nazwę (pochodzenia hebrajskiego) w liczbie pojedynczej i w dialekcie południowym (większość materiałów zapisano w tym właśnie dialekcie) - dla czytelności również w ortografii polskiej. 


\section{Język}

W zdecydowanej większości przypadków skatalogowane druki powstały w języku hebrajskim. Jeśli chodzi o rękopisy, to są one najczęściej wielojęzyczne - źródeł rękopiśmiennych napisanych w jednym języku jest niewiele. Zwykle mamy do czynienia z rękopisami hebrajskimi, w których zamieszczano teksty karaimskie - np. przekłady hebrajskich utworów. W zbiorach tych znajdziemy również rękopisy powstałe wyłącznie w języku karaimskim, jednak ich liczba jest ograniczona i są one zwykle nie starsze niż druga połowa XIX wieku. Oprócz tekstów napisanych językiem hebrajskim i karaimskim, znajdziemy też teksty w języku polskim, rosyjskim oraz kilka krótkich wstawek w języku arabskim, francuskim, krymskotatarskim, litewskim, tureckim i włoskim. Zob. także punkt następny.

\section{Dialekt karaimski}

Analiza dialektalna tekstów jest niezwykle ważna w świetle faktu, iż nie istniała jedna ponaddialektalna norma języka karaimskiego w czasach, gdy powstawały zabytki językowe w tym języku. Badania historyczno-językoznawcze należy więc prowadzić w podziale na poszczególne dialekty ${ }^{24}$. Używany był on w trzech podstawowych odmianach; chodzi o dwa warianty dialektu, lub języka ${ }^{25}$, zachodniokaraimskiego oraz o dialekt, lub język, wschodniokaraimski. Ogólnie rzecz ujmując, zachodniokaraimski był, i częściowo nadal jest językiem ojczystym Karaimów polsko-litewskich. Jego wariant północny to język Karaimów Litwy (ale był on na przykład używany również przez część Karaimów z Kukizowa), jego wariantem południowym zaś posługiwali się Karaimi z Halicza i Łucka. Dialekt wschodniokaraimski używany był na Krymie oraz w różnych innych miejscach w Rosji (zob. np. punkt 6), do których dotarli emigranci z Krymu. Różnica między dialektem wschodnim a dwoma dialektami zachodnimi jest znacząca (różni się leksyka, morfologia, fonologia i składnia; dialekty zachodnie są do siebie bardzo podobne) i pod tym względem identyfikacja języka tekstu nie sprawia żadnych trudności. Pomocna jest tu również wyraźna różnica między kursywą i półkursywą pisma hebrajskiego używanego

24 Oczywiście dotyczy to historii każdego języka: historia języka sprzed okresu powstania ponaddialektalnej normy to w zasadzie dialektologia historyczna.

25 Nie ma jednoznacznych kryteriów językoznawczych, które pozwoliłyby ustalić wyraźną granicę między językiem a dialektem. Dla potrzeb opisów katalogowych przyjęto określenia: język karaimski, język lub dialekt zachodniokaraimski, język lub dialekt wschodniokaraimski, dialekt południowozachodni i dialekt północnozachodni, zob. dalsze wyjaśnienia niżej. 
przez Karaimów z tych dwóch obszarów geograficznych - wystarczy rzut oka na rękopis by z dużą dozą prawdopodobieństwa ustalić czy mamy do czynienia z tekstem wschodnio- lub zachodniokaraimskim.

Z kilku przyczyn trudniejsza jest dokładna afiliacja dialektalna niektórych tekstów zachodnich.

Przede wszystkim należy zaznaczyć, że w zdecydowanej większości przypadków rozróżnienie tekstu północnozachodniego od południowozachodniego nie sprawia problemów - w szczególności, gdy mamy do czynienia z tekstami napisanymi pismem cyrylickim i łacińskim lub wokalizowanym pismem hebrajskim. Istnieje szereg kryteriów fonologicznych, które nam to umożliwiają ${ }^{26}$. Trudności mogą się jednak pojawiać w przypadku tekstów starszych pisanych bezwyjątkowo pismem hebrajskim przez nieznanych nam kopistów. Wiele z tych tekstów jest niewokalizowana, a użyte do zapisu pismo uniemożliwia rozróżnienie wielu par minimalnych (np. zapis samogłosek $a$ i $e$ w wielu pozycjach może być taki sam, rozróżnienie samogłosek $\ddot{o}, \ddot{u}$ od 'o i 'u jest niemożliwy, w wyniku czego zapis jest niejednoznaczny. W takich sytuacjach często możliwe były dwa lub teoretycznie nawet trzy (wliczając język wschodniokaraimski) poprawne odczyty pojedynczego wyrazu - w zależności od tego, jakie różnice dialektalne zostały odzwierciedlone przez zapis i czy w ogóle zostały jakieś odzwierciedlone. Co więcej, do momentu rozpoczęcia prac nad rękopisami, najstarsze znane i krytycznie wydane teksty zachodniokaraimskie pochodziły z pierwszej połowy XIX wieku, toteż wraz z postępem badań należało na bieżąco identyfikować i naukowo opisywać nieznane dotychczas cechy archaiczne i rozwój historyczny obu dialektów. Ustalono między innymi, że pewne cechy z pozoru wskazujące na proces mieszania się dialektu północnozachodniego i południowozachodniego należy tłumaczyć stopniem archaizmu tekstów - innymi słowy, formy wyglądające na północnozachodnie są w istocie archaicznymi formami południowozachodnimi ${ }^{27}$. W takich sytuacjach, aby przyjąć poprawny odczyt, należało cały rękopis poddać wnikliwej analizie językowej, ustalić tożsamość autorów, tłumaczy utworów i kopisty oraz miejsce i datę powstania rękopisu.

Sprawę komplikuje fakt, że kopiści bardzo często kopiowali utwory lub tłumaczenia utworów Karaimów mówiących i piszących nie ich (tzn. kopistów)

26 O tym szerzej zob. np. Németh (2011a: 11-30; 2015b; 2016b).

27 Ponieważ artykuł ten nie jest odpowiednim miejscem na przeprowadzenie wyczerpujących analiz językowych, czytelnika należy odesłać do artykułów tym kwestiom poświęconych, zob. prace Németha (przede wszystkim 2014a, 2015b, 2016b, 2016c oraz 2009, 2010, 2014b, 2014c) 
ojczystym dialektem. Zidentyfikowano kilkadziesiąt takich tekstów, w których kopiści pozostawiali cechy językowe charakterystyczne nie dla ich dialektu, ale dla dialektu (lub idiolektu) autora kopiowanego tekstu (zob. punkt następny).

\section{Glosy}

W tej rubryce została odnotowana obecność w danym tekście wyrazów lub wyrażeń wziętych z innego języka lub dialektu niż język lub dialekt analizowanego tekstu. Najczęstsze są interdialektalne wstawki oraz wyrazy lub fragmenty hebrajskie, polskie i rosyjskie użyte w tekstach karaimskich.

\section{Rodzaj pisma}

Do wydania druków użyto przede wszystkim czcionek hebrajskich, ale znajdziemy w zbiorach również druki cyrylickie lub powstałe pismem łacińskim (te ostatnie to głównie prace XX-wieczne).

Większość materiałów rękopiśmiennych została utrwalona pismem hebrajskim, znajdziemy jednak również teksty pisane pismem łacińskim (te napisane w języku karaimskim oparte są albo na polskiej albo na litewskiej grafii) i cyrylickim. W dwóch manuskryptach odnaleziono krótkie fragmenty pismem arabskim.

\section{Styl pisma}

Odręczne pismo hebrajskie było przez Karaimów używane w trzech odmianach: w odmianie kursywnej, półkursywnej i kwadratowej. Pismo kursywne stosowano przede wszystkim do zapisu nagłówków hebrajskich i nigdy nie było one wokalizowane (z nielicznymi wyjątkami) zaś pisma półkursywnego używano do zapisu tekstu głównego rękopisów. Owe dwa style pisma znane są również jako kursywa i półkursywa karaimska. Wstępnie możemy powiedzieć, że kształt liter pisma półkursywnego używanego przez Karaimów północnozachodnich różnił się tylko nieznacznie od tego używanego przez Karaimów południowozachodnich. Kwestia ta wymaga jednak pogłębionych badań. Znacząco odmiennej półkursywy i kursywy używano na Krymie ${ }^{28}$. Po trzecie wreszcie,

28 Najbardziej wyczerpujący opis kształtu liter i tendencji ortograficznych a także próbki pisma Karaimów z XIX i XX w. znajdziemy w pracy Németha (2011b: 99-135; 372-398). Drugi tom pracy Aqtay (2009) zawiera obszerne facsimile krymskokaraimskiego tekstu. Przegląd różnych stylów pisma hebrajskiego (w tym również tego używanego przez różne narodowości wyznające religię karaimską) znajdziemy na przykład w pracach Birnbauma (1954-1957: ryc. 359-365, 393), Yardeni (1997) lub Trzcińskiego (2004: 79-82). 
niektóre szczególnie ważne fragmenty (np. kolofony) lub incipity kaligrafowano pismem kwadratowym (litery kształtem przypominają litery drukowane).

Tej rubryki nie wypełniano w przypadku opisu druków.

\section{Wokalizacja}

Rękopisy zawierające teksty karaimskie zapisane pismem hebrajskim zostały dodatkowo sklasyfikowane pod kątem obecności wokalizacji. Opisano je według czterech kategorii: teksty wokalizowane, częściowo niewokalizowane (= w większości wokalizowane), częściowo wokalizowane (= w większości niewokalizowane) oraz niewokalizowane. Wokalizacja była zwykle nanoszona przez kopistów po napisaniu liter wyrazu (wskazują na to liczne przypadki skreślenia wyrazu niewokalizowanego w środku tekstu wokalizowanego) lub po napisaniu całego tekstu bez wokalizacji (wskazują na to przypadki dodania wokalizacji innym, cieńszym piórem lub innym atramentem). Ciekawym zjawiskiem są wspomniane w punkcie 6 rzadkie przypadki obecności wokalizacji zgodnej z systemem fonologicznym dialektu południowozachodniego w tekście pierwotnie napisanym dialektem północnozachodnim.

\section{Oprawa}

Rubryki 20-26 poświęcono opisowi fizycznemu źródeł. W pierwszej kolejności opisano oprawę lub odnotowano jej brak czy zniszczenie. Do oprawiania rękopisów używano najczęściej tektury lub drewna. Oblekano je skórą lub płótnem - najczęściej w kolorze brązowym. Często stosowano wytłoczenia zdobiące oprawę, ale podawano w ten sposób również tytuły dzieł lub imiona czy też inicjały ich właścicieli. W nielicznych przypadkach zachowały się również klamry metalowe spinające blok. Bardzo często stosowano karty ochronne na początku i końcu bloku. W dużej liczbie przypadków oprawy są zniszczone, źle umocowane, grzbiety obiektów są często niezachowane lub oddzielone od wiązań grzbietu. W tej rubryce szacowano również datę wykonania oprawy. Zob. punkt 24.

\section{Papier}

Opis papieru użytego do stworzenia rękopisu zawiera podstawowe informacje, takie jak technika jego wykonania (czerpany, maszynowy), jego faktura (żeberkowy, gładki), kolor, znaki papierni oraz obecność lub brak filigranów.

\section{Atrament}

Opis atramentu ogranicza się do określenia jego koloru. Odnotowano również użycie bardziej podatnego na korozję atramentu żelazowo-galusowego. 


\section{Liczba stron / Liczba kart}

Opis źródła zawiera określenie liczby stron lub kart oraz informację czy strony lub karty były numerowane. Nienumerowane karty rękopisów ponumerowano podczas inwentaryzowania - ręcznie, ołówkiem miękkim. W przypadku druków ze wstawkami rękopiśmiennymi liczbę stron lub kart druku i rękopisu podano osobno, jednocześnie określając kolejność kart druku i rękopisu. Na przykład w przypadku rkp. JSul.III.71 wygląda to następująco: „Liczba kart: 160 kk. druku

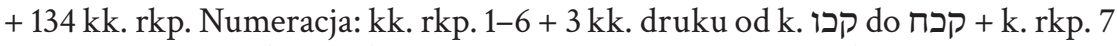

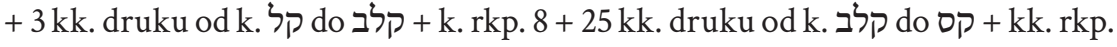

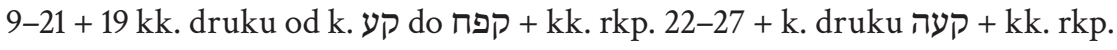

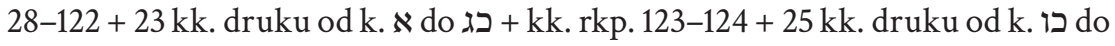
[מט] + 1 k. druku nlb. + k. 125 rkp. +5 kk. druku nlb. + 51 kk. druku od k. J do k. ק + kk. rkp. 126-127 + 4 kk. druku od k. קב do p. rkp. 128-134."

W przypadku rękopisów z niezachowaną integralnością bloku kolejność kart należało zweryfikować i w nielicznych przypadkach poprawić. Konieczność odtworzenia pierwotnej kolejności kart wiązała się zwykle z tym, że właściciele często wsuwali w środek rękopisów poluzowane karty początkowe lub końcowe.

O niektórych kartach odnalezionych luzem okazywało się, że przynależą do rękopisów wcześniej już opracowanych. Wówczas odnalezionym kartom nadawano numery z literami A, B, C, by nie numerować kart danego rękopisu ponownie i nie narażać tym samym rękopisu na dalsze zniszczenia (zob. np. ADub.III.86: kk. 40a-c).

\section{Stan zachowania}

Opis stanu zachowania danej jednostki zawiera przede wszystkim informacje o obecności zniszczeń, jak np. zniszczenia oprawy, stan integralności bloku, kompletność rękopisu (woluminy noszą w wielu przypadkach ślady intensywnego używania; wiele rękopisów to fragmenty pozbawione oprawy), atak mikrobiologiczny, ślady żerowania owadów lub gryzoni, zacieki, obecność posklejanych kart, nadpalenia, uszkodzenia mechaniczne takie jak ślady użytkowania, postrzępienia marginesów, ubytki w papierze, ubytki w treści czy korozja atramentu. W opisie odnotowano również ślady wcześniejszych napraw i podklejeń (zwykle przy użyciu kwaśnego papieru), oceniano stopień czytelności samego tekstu. Wiele obiektów zachowało się w stanie dobrym, niestety jednak duża liczba rękopisów i druków wymaga natychmiastowej i kosztownej konserwacji. W latach 2012-2016 część najbardziej zagrożonych, a jednocześnie najcenniejszych, jednostek została z inicjatywy Marioli Abkowicz i Anny Sulimowicz poddana profesjonalnej konserwacji przez pracowników Zakładu 
Konserwacji Papieru i Skóry Uniwersytetu Mikołaja Kopernika w Toruniu dzięki wsparciu finansowemu Ministerstwa Kultury i Dziedzictwa Narodowego (zob. Pronobis-Gajdzis 2014; 2015; 2016; Jabłońska 2016) ${ }^{29}$. Do tej pory ukończono konserwację łącznie 33 obiektów przechowywanych w zbiorach Józefa Sulimowicza, Aleksandra Dubińskiego i Rafała Abkowicza ${ }^{30}$.

\section{Format bloku}

Dane w milimetrach.

\section{Format karty}

Dane w milimetrach.

\section{Liczba wierszy na stronę}

Nie podawano liczby wierszy na stronę w odniesieniu do druków. W przypadku rękopisów w rubryce tej podano dominującą liczbę wierszy na stronę. Dane liczbowe podawano w zakresie od najmniejszej do największej liczby wierszy. Kierowano się w tym miejscu zdrowym rozsądkiem i nie uwzględniano wierszy zawieszonych lub liczby wierszy na końcowych kartach rękopisów lub rozdziałów, które - z przyczyn oczywistych - bardzo często pozostawały częściowo niezapełnione. Zaznaczyć również zależy, że w rękopisach kopiowanych przez profesjonalnych kopistów liczba wierszy na stronę najczęściej była stała.

\section{Początek rękopisu}

W celu łatwiejszej identyfikacji rękopisu, w opisie zamieszczono pierwsze kilka wyrazów całego rękopisu lub jego zachowanego fragmentu (najczęściej są to wyrazy hebrajskie).

29 W przypadku tak dużych zbiorów jak kolekcja Józefa Sulimowicza wytypowanie obiektów do konserwacji i ustalenie kolejności, w jakiej owe jednostki powinno być ratowane (otrzymanie finansowania na kolejne lata zależało od rozstrzygnięć konkursowych), było poważnym zadaniem badawczym trwającym kilka miesięcy. Plan ratowania najcenniejszych pozycji został utworzony przez konserwator zabytków, panią Magdalenę Dalke we współpracy z Anną Sulimowicz, zob. Dalke (2013), Pronobis-Gajdzis (2014: 223-227).

30 Są to jednostki o sygnaturach ADub.III.61, ADub.III.73, ADub.III.78, ADub.III.86, JSul.I.04, JSul.I.05, JSul.I.06, JSul.I.11, JSul.I.12, JSul.I.13, JSul.I.18, JSul.I.20, JSul.I.23, JSul.I.25, JSul.I.45, JSul.I.46, JSul.II.01, JSul.II.02, JSul.II.05, JSul.III.01, JSul.III.02, JSul.III.05, JSul.III.64, JSul.III.65, JSul.III.66, JSul.III.67, JSul.III.70, JSul.III.72, JSul.III.73, JSul.III.75, JSul.III.79, RAbk.IV.01, RAbk.IV.03. 


\section{Koniec rękopisu}

W celu łatwiejszej identyfikacji rękopisu, w opisie zamieszczono ostatnie kilka wyrazów całego rękopisu lub jego zachowanego fragmentu (najczęściej są to wyrazy hebrajskie).

\section{Uwagi}

W uwagach umieszczano komentarze dotyczące wątpliwości związanych z ustaleniem czasu i miejsca powstania zabytku językowego oraz tożsamości autorów, tłumaczy lub kopistów. Poza tym znajdziemy tu również wyjaśnienia dotyczące metody, jaką powyższe informacje zostały przez zespół badawczy ustalone oraz wszelkie szczegóły dotyczące historii samego obiektu (a więc dotyczące jego właścicieli, miejsca przechowywania w przeszłości itd.). Gdy danym rękopisem lub drukiem zajmowano się już w literaturze fachowej, w tym miejscu umieszczano również odsyłacze do tych prac.

\section{Znaczenie skatalogowanych źródeł dla nauki}

W 1959 roku Omeljan Pritsak w swym artykule wydanym w pierwszym tomie Philologiae Turcicae Fundamenta ${ }^{31}$ streścił historię badań filologicznych nad źródłami karaimskimi i podsumował ją następującymi słowami: „Trotz dieser schönen Arbeiten steht die karaimische Philologie immer noch im Anfangsstadium. Der wesentliche Teil der Handschriften harrt noch immer der Veröffentlichung und Bearbeitung." (Pritsak 1959: 324). O edycjach źródeł przeprowadzonych do momentu rozpoczęcia opisywanego projektu badawczego (a więc do 2012 roku) wspomniano już we wstępie niniejszego artykułu - wobec ich liczby widzimy więc, że słowa Pritsaka pozostają nadal aktualne. O konieczności podjęcia rzetelnych badań opartych na edycji tekstów pisał już zresztą Kowalski (1935-1936: 19-20). I choć z badań nad językiem niektórych rękopisów oraz przekładów Tory przechowywanych w zbiorach prywatnych oraz z uwag umieszczanych na marginesach kart tych woluminów wynika, że osoby gromadzące materiał językowy na potrzeby Słownika karaimsko-polsko-rosyjskiego (KarRPS) wydanego w 1974 r. korzystały z części skatalogowanych źródeł (był wśród nich np. Aleksander Dubiński), to jednak materiały te ostatecznie nie doczekały się wydań krytycznych.

\footnotetext{
31 Tom ten był ambitnym przedsięwzięciem przedstawienia ówczesnej wiedzy o językach turkijskich w sposób usystematyzowany.
} 
Przyznać jednak trzeba, że w ostatnich latach sytuacja się nieco poprawiła a perspektywy badań są coraz lepsze. $Z$ jednej strony zawdzięczamy to coraz większemu zainteresowaniu kulturą (w tym także językiem) karaimską z racji jej unikatowości oraz z racji jej zagrożonego bytu. Z drugiej strony turkolodzy coraz częściej zajmują się historią tego języka, choć badania nad językiem żywym są utrudnione z uwagi na coraz mniejszą liczbę osób tym językiem się posługują$\mathrm{cych}^{32}$. Coraz większym zainteresowaniem cieszą się więc nieprzebadane jeszcze źródła Karaimów polsko-litewskich, zarówno te w języku karaimskim, jak i te w języku hebrajskim, o czym świadczą niedawno powstałe prace Jankowskiego (2014), Kizilowa (2007, 2009, 2013), Muchowskiego (2013a, 2013b, 2014), Németha (2014a; 2014b; 2014c; 2014d; 2015a; 2015b; 2015c; 2015d; 2016a; 2016b; 2016c), Olach (2012, 2013, 2014, 2015), Stachowskiego (2015) czy Sulimowicz (2013, 2015d) oraz fakt założenia w Polsce dwóch czasopism karaimoznawczych (w 2013 roku): Almanach Karaimski (Wrocław) i Karaite Archives (Poznań). Wreszcie niedawno powstałe prace historyczne, jak np. książki i artykuły Abkowicz (2014; 2015), Gąsiorowskiego (2008), Kalety (2015), Kizilova (2009; 2015), Pawelca (2015), Sulimowicz (2014; 2015b; 2015c; 2015e, 2016), Szabarowskiego [= Šabarovśkyj] (2013) czy Witkowskiego (2014, 2015a; 2015b; 2015c) wyraźnie podkreślają wagę i potrzebę badań źródłowych. Katalog wychodzi więc naprzeciw tym potrzebom.

Badania przeprowadzone podczas opracowywania zawartości kolekcji rękopisów i starodruków w znacznym stopniu poszerzyły wcześniejszą wiedzę o piśmiennictwie karaimskim. Dzięki pracom nad ustaleniem miejsca i czasu powstania rękopisów oraz nad tożsamością autorów, tłumaczy i kopistów, badania historyczno-językoznawcze zyskały nowe perspektywy. Dotyczy to nie tylko badań nad historią języka karaimskiego, ale również nad językami zachodniokipczackimi, bowiem język karaimski, z racji stopnia archaiczności zachowanych w nim elementów rodzimych, jest dla turkologów bardzo istotnym źródłem wiedzy o tej grupie języków ${ }^{33}$. Ustalenia te mają kardynalne znaczenie, bowiem rękopis zawierający szereg unikatowych cech językowych traci na swojej wartości dla nauki, jeśli nie jesteśmy w stanie przyporządkować go odpowiedniemu okresowi rozwoju języka lub obszarowi geograficznemu.

32 W roku 2003 znajomość tego języka na Litwie zadeklarowało łącznie 97 osób (Adamczuk i in. 2003: 65). Mówią oni dialektem północnozachodnim. Dialekt południowozachodni oraz wschodni należy uznać za wymarłe.

33 Ciekawie zapowiadają się na przykład badania porównawcze między językiem zachodniokaraimskim a językiem ormiańsko-kipczackim. Niedawno powstały dwie prace dotyczące tej tematyki, zob. Olach (2011), Németh (2013d). 
W przypadku języka karaimskiego wiele kwestii wciąż czeka na należyte opracowanie. Bazując na wiedzy zdobytej podczas lektury katalogowanych źródeł, można było się podjąć pierwszej próby opisu periodyzacji języka karaimskiego (zob. Németh 2015b; 2016b) - rzeczy oczywistej i dobrze znanej w przypadku języków ze znacznie większym dorobkiem piśmienniczym. Oprócz tego dokonano wstępnych opisów językowych kontaktów interdialektalnych (Németh 2012, 2013a, 2013b) oraz historii zmian fonologicznych i morfologicznych opartych nie na rekonstrukcji, ale na sprawdzonych danych filologicznych (od początku XVIII w.; zob. Németh 2014a; 2014b; 2014c; 2014d; 2015a; 2015b; 2016b; 2016c). Można więc z większą szczegółowością pisać o naturze zmian, które ukształtowały język karaimski w jego znanej formie oraz o ich chronologii względnej i bezwzględnej, ale także o wpływach obcych czy wręcz stylistyce (Németh 2013c).

Odnalezienie najstarszych znanych przekładów ksiąg Starego Testamentu na język zachodnio- i wschodniokaraimski ma fundamentalne znaczenie nie tylko dla historii języka, lecz także dla kultury karaimskiej (więcej o nich zobacz: Németh 2014b; 2014d; 2015c; 2015d; 2016a). Pełne edycje krytyczne tych rękopisów stworzyłyby możliwość dokonania dalszych analiz porównawczych, np. z dostępnymi drukami Tanachu, a w tym przede wszystkim z krymskokaraimskim drukiem z 1841 z Eupatorii, którego język jest niejednorodny i istnieje podejrzenie, że podczas pracy nad nim korzystano ze źródeł zachodniokaraimskich ${ }^{34}$. Co więcej, byłyby one istotnym źródłem wiedzy dla badaczy prowadzących badania kontrastywne nad judaizmem i karaimizmem.

Katalog więc z całą pewność posłuży w przyszłości jako punkt wyjścia do dalszych, niezbędnych badań historycznych, językoznawczych, literaturoznawczych, etnograficznych, kulturoznawczych oraz religioznawczych.

\section{Znaczenie skatalogowanych źródeł dla kultury}

Inwentaryzacja źródeł przechowywanych w prywatnych archiwach umożliwia realną ocenę tego, jak bogate i cenne są źródła karaimskie dostępne w Polsce. Dużą część opracowanego materiału można nazwać w pewnym sensie pomnikami kultury. Pamiętać należy, że niemal wszystkie obiekty materialne kultury

$34 \quad$ Rkp. ADub.III.73 jest w chwili obecnej przedmiotem badań projektu badawczego Najstarszy znany przekład ksiag Starego Testamentu na język Karaimów polskich. Edycja krytyczna rękopisu Tory z $1720 \mathrm{r}$. finansowanego z programu OPUS Narodowego Centrum Nauki (nr projektu 2015/17/B/HS2/01498). 
Karaimów po 1945 r. znalazły się poza granicami Polski (wyjątek stanowi jedyny w Polsce cmentarz karaimski w Warszawie przy ul. Redutowej $34^{35}$ ). Toteż przywiezione w czasie migracji czy repatriacji rękopisy i starodruki stanowią ostatni ślad duchowej kultury tej społeczności. Jednocześnie są one zabytkiem ginącego języka, wymienionego w Czerwonej Księdze języków zagrożonych UNESCO.

\section{Baza danych}

$\mathrm{Na}$ chwilę obecną katalog jest wydany wyłącznie w formie XML-owej bazy danych operującej na danych w formacie TEI P5 (zob. Németh \& Sulimowicz \& Abkowicz 2015) utworzonej we współpracy z zespołem Poznańskiego Centrum Superkomputerowo-Sieciowego afiliowanego przy Instytucie Chemii Bioorganicznej PAN. Decyzja ta została podyktowana względami praktycznymi. Po pierwsze autorzy katalogu chcieli jak najprędzej i w jak najszerszym obiegu udostępnić wyniki badań. Po drugie, jako że katalog zawiera opisy rękopisów i druków karaimskich przechowywanych w Polsce w nieinwentaryzowanych dotychczas zbiorach prywatnych, szansa na odnalezienie dalszych jednostek, o których istnieniu wcześniej nie wiedzieliśmy, jest duża. Baza stanowi najwygodniejsze rozwiązanie, gdyż można ją na bieżąco uzupełniać o kolejne rekordy. Ma ona również tę przewagę nad drukowanym katalogiem, że w razie potrzeby można aktualizować istniejące już rekordy, wprowadzając wyniki najnowszych badań. W przyszłości planowane jest jednak angielskojęzyczne wydanie książkowe.

\section{Bibliografia}

Abkowicz, Mariola. 2007. Karaimi Galicji w księgach metrykalnych trockiego zarządu duchownego. - Jakubowska, U. (red.): Galicyjskie spotkania. Warszawa.

Abkowicz, Mariola, 2008. Karaimska antroponimia w XIX i XX w. w świetle ksiąg metrykalnych Karaimskiego Zarządu Duchownego w Trokach. - Bairašauskaité, T., Kobeckaite, H., Miškinienè, G. (red.): Orientas Lietuvos Didžiosios Kunigaikštijos visuomenes tradicijoje: totoriai ir karaimai (= Straipsniu rinkinys, parengtas pranešimu, skaitytu tarptautineje mokslo konferencijoje „,10-osios totoriu ir karaimu i isikürimo Lietuvos Didžiojoje Kunigaikštijoje metinès" 2007 m. rugsëjo 13-15 d. Vilniaus universitete, pagrindu). Vilnius: 169-178.

Abkowicz, Mariola. 2012. Karaimskie życie społeczne w Polsce po 1945 roku. - Machul-Telus, B. (red.): Karaimi. Warszawa: 180-205.

Abkowicz, Mariola. 2014. Na tropach dziejów rodziny. Hazzan Ananiasz Abkowicz i jego potomkowie. - Awazymyz 3 (44): 4-7.

35 O cmentarzu zob. Dubiński, Adam (2013). 
Abkowicz, Mariola. 2015. Towarzystwo edukacyjne „Limmud Tora”. Reforma szkolnictwa karaimskiego na początku XX w. w Trokach w świetle dokumentów. - Almanach Karaimski 4: 147-165.

Abkowicz, Mariola \& Sulimowicz, Anna. 2010. Karaj jołłary - karaimskie drogi. Karaimi $w$ dawnej fotografii. Wrocław.

Abkowicz, Mariola \& Sulimowicz, Anna Akbike \& Kameduła, Joanna. 2015. e-Jazyszłar. Karaimskie Archiwum Cyfrowe. Tom. 1. Karaimska baza literacko-bibliograficzna. Wrocław [dostępne pod adresami www: https://jazyszlar.karaimi.org/journals; https:// jazyszlar.karaimi.org/books; https://jazyszlar.karaimi.org/songs].

Abkowicz, Rafał. 1999. Wspomnienie. - Awazymyz 1 (2): 4-5.

Adamczuk, Lucjan i in. (red.). 2003. Karaimi na Litwie i w Polsce. Warszawa.

Aqtay, Gulayhan. 2009. Eliyahu ben Yosef Qllcis anthology of Crimean Karaim and Turkish literature. Critical edition with introduction, indexes and facsimile. (= Ylldz Dil ve Edebiyat Dizisi 8). Tom 1-2. İstanbul.

Birnbaum, Solomon A. 1954-1957. The Hebrew Scripts. Part Two: The Plates, London.

Csató, Éva Ágnes. 2002. Tïnčlïx džanïna! To the memory of Aleksander Dubiński (1924-2002). - Turkic Languages 6/2: 153-156.

Dalke, Magdalena. 2013. Ocena konserwatorska książek karaimskich z księgozbioru Józefa Sulimowicza. Toruń [niepublikowana praca magisterska, UMK ZJPiS].

Dobosz, Krzysztof. 2012. Początki i pierwszy tom „Rocznika Orientalistycznego”. Przyczynek do dziejów czasopisma. - LingVaria 7/2 (14): 177-193.

Dubiński, Adam. 2010. Aleksander Dubiński. - Awazymyz 2 (27): 3-6.

Dubiński, Adam. 2013. Karaimi i ich cmentarz w Warszawie. - Machul-Telus, B. (red.): Karaimi. Warszawa: 145-179; 230-240.

Dubiński, Aleksander. 1973. Józef Sulimowicz (1913-1973). - Przegląd Orientalistyczny 4 (88), s. 365-366.

Dubiński, Aleksander. 1979. Karaimische Handschriften in polnischen Sammlungen. - Central Asiatic Journal 23/3-4: 147-150.

Dubiński, Aleksander. 1985. Karaimskie rukopisi iz kollekcii Ju. Sulimoviča v Varšave. -Abdurachmanov, G. A., Chodžiev, A. P. i in. (red.): Tjurkskoe jazykoznanie. Materialy III vsesojuznoj tjurkologičeskoj konferencii. Taškent 10-12.IX.1980. Taškent: 20-24 [non vidi, autor korzystał z maszynopisu artykułu].

Dubiński, Aleksander. 1988. Fragmenty korespondencji prof. Tadeusza Kowalskiego z Aleksandrem Mardkowiczem. - Przeglad Orientalistyczny 1 (145): 62-67.

Dziurzyńska, Ewa. 1999. Podróże naukowe Tadeusza Kowalskiego w świetle materiałów archiwalnych. - Majkowska, R. (red.): Tadeusz Kowalski 1889-1948. Materiały $z$ Posiedzenia Naukowego PAU $w$ dniu 19.VI.1998 $r$. (= W służbie nauki 4). Kraków: 29-53.

Eĺjaševič, Boris Saad́evič. 1993. Karaimskij biografičeskij slovaŕ (ot konca XIII v. do 1960 g.) (= Institut Ètiologii i Antropologii RAN. Materialy k serii «Narody i kultury» 14, Karaimy. Kniga 2), Moskva.

Gąsiorowski, Stefan. 2008. Karaimi $w$ Koronie i na Litwie w XV-XVIII wieku. Kraków, Budapeszt. 
Grzegorzewski, Jan. 1903. Ein türk-tatarischer Dialekt in Galizien. Vokalharmonie in den entlehnten Wörtern der karaitischen Sprache in Halicz. (Mit Einleitung, Texten und Erklärungen zu den Texten). - Sitzungsberichte der kais[erlichen] Akademie der Wissenschaften in Wien. Philosophisch-historische Klasse 146: 1-80.

Grzegorzewski, Jan. 1918. Caraimica. Język Łach-Karaitów. - Rocznik Oryentalistyczny 1/2 (1916-1918): 252-296.

Jabłońska, Elżbieta. 2016. Prace konserwatorsko-restauratorskie nad karaimskimi rękopisami i starodrukami przeprowadzone w 2016 r. - Almanach Karaimski 5: 249-253. Jankowski, Henryk. 2003a. On the language varieties of Karaims in the Crimea. - Studia Orientalia 95: 109-130.

Jankowski, Henryk. 2003b. Position of Karaim among the Turkic Languages. - Studia Orientalia 95: 131-150.

Jankowski, Henryk. 2009. Translations of the Bible into Karaim. - Religion Compass 3/4: 502-523.

Jankowski, Henryk. 2011. Two prayers for the Day of Atonement in translation into the Luck-Halicz dialect of Karaim. - Shapira, D. Y., Lasker, D. J. (we współpracy z Akhiezer, G., Kizilov, M. (red.): Eastern European Karaites in the last generations. Jerusalem: 156-170.

Jankowski, Henryk. 2012. Literatura krymskokaraimska. - Przeglad Orientalistyczny 1 (241): 50-67.

Jankowski, Henryk. 2013. Karaim mejumas in Eupatoria. - Pang, T., Raschman, S.-Ch., Winkelhane, G. (red.): Unknown treasures of the Altaic world in libraries, archives and museums. 53rd annual meeting of the Permanent International Altaistic Conference, Institute of Oriental Manuscripts, RAS St. Petersburg, July 25-30, 2010. Berlin: 245-262.

Jankowski, Henryk. 2014. Two Karaim religious poems by Isaac ben Abraham Troki. - Karaite Archives 2: 35-57.

Kaleta, Petr. 2015. Tajemné etnikum z Krymu. Osudy príslušníkủ emigrace do meziválečného Ceskoslovenska. Praha.

Kałużyński, Stanisław. 1994. Aleksander Dubiński septuagenarius. - Majda, T. (red.): Caraimica. Prace karaimoznawcze. Warszawa: 13-20.

KarRPS = Baskakov, N. A., Šapšal, S. M., Zajončkovskij, A. (red.), Karaimsko-russko-poĺskij slovaŕ. Słownik karaimsko-rosyjsko-polski, Moskva 1974.

Kizilov, Mikhail. 2007. Two Piyyutim and a Rhetorical Essay in the Northern (Troki) Dialect of the Karaim Language by Isaac ben Abraham of Troki. - Judaica 63/1-2: 64-75.

Kizilov, Mikhail. 2009b. Plague in Lithuania, Desolation in Jerusalem: Two Poems in the Karaim Language from Tadeusz Kowalski's Archival Collection. - Judaica 65/2: 193-209.

Kizilov, Mikhail. 2009b. The Karaites of Galicia. An ethnoreligious minority among Ashkenazim, the Turks, and the Slavs. 1772-1945 (= Studia Judeoslavica 1). Leiden, Boston.

Kizilov, Mikhail. 2013. Jan Grzegorzewski's Karaite materials in the archive of the Polish Academy of Sciences in Kraków. - Karaite Archives 1: 59-84.

Kizlov, Mikhail. 2015. The Sons of Scripture. The Karaites in Poland and Lithuania in the twenieth century. [Książka elektroniczna]. 
Kowalski, Tadeusz. 1929. Karaimische Texte im Dialekt von Troki (= Prace Komisji Orjentalistycznej Polskiej Akademji Umiejętności 11). Kraków.

Kowalski, Tadeusz. 1930. Z pożółkłych kart. - Myśl Karaimska 2 (3-4): 12-25.

Kowalski, Tadeusz. 1934. Materiały karaimskie śp. Jana Grzegorzewskiego. - Myśl Karaimska 10: 19-28.

Kowalski, Tadeusz. 1935-1936. Najpilniejsze zadania karaimoznawstwa. - Myśl Karaimska 11: 12-23.

Mann, Jacob. 1931. Texts and Studies in Jewish History and Literature. Volume II: Karaitica. New York [wydanie drugie: 1972].

Muchowski, Piotr. 2013a. Folk literature of the Polish-Lithuanian Karaites. Abkowicz 3 manuscript. Part 2. Paris.

Muchowski, Piotr. 2013b. Pas Yeda' and Massa' ha-'Am: The lost works of Avraham ben Yoshiyahu (Abraham Ezyaszewicz). - Karaite Archives 1: 85-112.

Muchowski, Piotr. 2014. Folklore of the Karaites in Lithuania: the Yehuda Bezekowicz manuscript from Troki, 1873. - Karaite Archives 2 (2014): 75-89.

Munkácsi, Bernát. 1909. Karäisch-tatarische Hymnen aus Polen. - Keleti Szemle 10: 185-210.

Németh, Michał. 2009. Errors with and without purpose: A. Mardkowicz's transcription of Łuck-Karaim letters in Hebrew script. - Studia Linguistica Universitatis Iagellonicae Cracoviensis 126: 97-106.

Németh, Michał. 2010. North-Western and Eastern Karaim Features in a Manuscript Found in Euck. - Mańczak-Wohlfeld, E., Podolak, B. (red.): Studies on the Turkic word. A Festschrift for Professor St. Stachowski on the Occasion of His 8oth birthday. Kraków: 75-94.

Németh, Michał. 2011a. Zwięzła gramatyka jezyka karaimskiego z ćwiczeniami (= Prace Karaimoznawcze 1). Poznań.

Németh, Michał. 2011b. Unknown Lutsk Karaim Letters in Hebrew script(19th-2oth Centuries). A Critical Edition (= Studia Turcologica Cracoviensia 12). Kraków 2011.

Németh, Michał. 2012. A North-Western Karaim manuscript found in Lutsk. A case of dialect mingling? - Studia Linguistica Universitatis Iagellonicae Cracoviensis 129: 139-162.

Németh, Michał. 2013a. Karaim letters of Jehoszafat Kapłanowski. I. A critical edition. - Studia Linguistica Universitatis Iagellonicae Cracoviensis 130: 237-257.

Németh, Michał. 2013b. Karaim letters of Jehoszafat Kapłanowski. II. Linguistic analysis. - Studia Linguistica Universitatis Iagellonicae Cracoviensis 130: 259-276.

Németh, Michał. 2013c. Karaim literature as a source of information on the spoken language. A case study of the early $20^{\text {th }}$-century Lutsk Karaim dialect. - Karaite Archives 1: 113-132.

Németh, Michał. 2013b. Uwagi językowe na marginesie ormiańsko-kipczackich tekstów w edycji Edwarda Tryjarskiego (2010). - Lehahayer 2: 251-261.

Németh, Michał. 2014a. A historical phonology of Western Karaim. Alveolars and front labials in the south-western dialect. - Studia Linguistica Universitatis Iagellonicae Cracoviensis 131/3: 247-267.

Németh, Michał. 2014b. A historical phonology of Western Karaim. The evolution of consonant harmony in the north-western dialect. - Studia Linguistica Universitatis Iagellonicae Cracoviensis 131/4: 353-368. 
Németh, Michał. 2014c. Adalék a Csángók kun eredetelméletének kritikájához. - Nyelvtudományi Közlemények 110: 183-190.

Németh, Michał. 2014d. An early North-Western Karaim Bible translation from 1720. Part 1. The Torah. - Karaite Archives 2: 109-141.

Németh, Michał. 2015a. A historical morphology of Western Karaim. The -p edi- past tense in the south-western dialect. - Acta Orientalia Academiae Scientiarum Hungaricae 68/2: 215-228.

Németh, Michał. 2015b. A historical phonology of Western Karaim. The process of its diversification into dialects. - Studia Linguistica Universitatis Iagiellonicae Cracoviensis 132: 167-185.

Németh, Michał. 2015c. An early North-Western Karaim Bible translation from 1720. Part 2. The Book of Ruth. - Karaite Archives 3: 49-102.

Németh, Michał. 2015d. An early North-Western Karaim Bible translation from 1720. Part 3. A contribution to the question of the stemma codicum of the Eupatorian print from 1841. - Karaite Archives 3: 103-118.

Németh, Michał. 2015e. Nowy słownik języka krymskokaraimskiego Gulayhan Aqtay i Henryka Jankowskiego (2015) z dyskusją nad odrębnością tego języka w klasyfikacji języków w tle. - Almanach Karaimski 4: 7-17.

Németh, Michał. 2016a. A Crimean Karaim handwritten translation of the Book of Ruth dating from before 1687. Another contribution to the history of Crimean Karaim and to the question of the stemma codicum of the Eupatorian printed edition of the Tanakh from 1841. - [w druku w:] Türk Dilleri Araştırmalan 26/2: 161-226.

Németh, Michał. 2016b. Batı Karaycasının Lehçelere Ayrılma Süreci ve Dönemselleştirilmesi. - [w druku w:] Eker, S., Şavk, Ü. Ç. (red.): Tehlikedeki Türk Dilleri. 4. Disiplinlerarası Yaklaşımlar. Endangered Turkic Languages. 4. Interdisciplinary Approaches. Ankara, Astana: 281-294.

Németh, Michał. 2016c. Güneybatı Karaycada /š, č/, /ž, ̌̌/ ünsüzlerinin ve /ö, ü/ ünlülerinin değişimleri (18. ve 19. yüzyıllar). - [w druku w:] Eker, S., Şavk, Ü. Ç. (red.): Tehlikedeki Türk Dilleri. 4. Disiplinlerarası Yaklaşımlar. Endangered Turkic Languages. 4. Interdisciplinary Approaches. Ankara, Astana: 295-309.

Németh, Michał \& Sulimowicz, Anna Akbike \& Abkowicz, Mariola. 2015. e-Jazyszłar. Karaimskie Archiwum Cyfrowe. Tom. 2. Baza danych o ręopisach i starodrukach karaimskich w polskich zbiorach prywatnych. Wrocław [dostępne pod adresem www: https:// jazyszlar.karaimi.org/manuscripts].

Olach, Zsuzsanna. 2011. A halicsi karaim Abrahamowicz Biblia vallási terminológiájának összehasonlító vizsgálata örmény-kipcsak források vallási terminológiájával. - [redaktorzy niepodani]: Nyelvészdoktoranduszok 15. Országos Konferenciája. 2011. november 17-18. Absztraktok. [Szeged]: 23 [Streszczenie referatu].

Olach, Zsuzsanna. 2012. Numerals in Halich Karaim Bible texts. - Kincses-Nagy, É., Biacsi, M. (red.): The Szeged Conference. Proceedings of the 15th International Conference on Turkish Linguistics held on August 20-22, 2010 in Szeged (= Studia Uralo-Altaica 49). Szeged. 
Olach, Zsuzsanna. 2013. A Halich Karaim translation of Hebrew biblical texts (= Turcologica 98). Wiesbaden.

Olach, Zsuzsanna. 2014. A comparative study of two evening prayers written in Karaim. - Demir, N., Karakoç, B., Menz, A. (red.): Turcology and Linguistics. Éva Ágnes Csató Festschrift. Ankara.

Olach, Zsuzsanna. 2015. Debated issues in Karaim Hebrew orthography. - Acta Orientalia Academiae Scientiarum Hungaricae 68/2: 183-197.

Pawelec, Mariusz. 2015. Nowe szczegóły z biografii Aleksandra Mardkowicza (1875-1944). Almanach Karaimski 4: 19-32.

Pilecki, Szymon. 2012. Karaimskie życie rodzinne, społeczne i religijne okresu międzywojennego, czas wojny, decyzje o przyjeździe do Polski. - Machul-Telus, B. (red.): Karaimi. Warszawa: 34-52.

Poznański, Samuel. 1909. Die karäische Literatur der letzten dreissig Jahre. - Zeitschrift für hebræische Bibliographie 13: 110-118, 140-151.

Poznański, Samuel. 1909. Nachtrag zur „Karäischer Literatur der letzten dreissig Jahre“. - Zeitschrift für hebræische Bibliographie 13: 180-818.

Poznański, Samuel. 1910. Zweiter Nachtrag zur „Karäischer Literatur der letzten dreissig Jahre“ . - Zeitschrift für hebræische Bibliographie 14: 57-61, 93-95, 112-115, 153-154.

Poznański, Samuel. 1912-1919. Karäisch-tatarische Literatur. - Keleti Szemle 13 (1912-1913): 37-47, 360; Keleti Szemle 14 (1913-1914): 223-224; Keleti Szemle 18 (1918-1919): 150-151.

Poznański, Samuel. 1918. Karäische Drucke und Druckereien. - Zeitschrift für hebræische Bibliographie 21: 32-48, 66-83.

Poznański, Samuel. 1920. Karäische Drucke und Druckereien. - Zeitschrift für hebræische Bibliographie 23: 63-68.

Pronobis-Gajdzis, Małgorzata. 2014. Komunikat z przebiegu prac konserwatorsko-restauratorskich przy książkach karaimskich w latach 2013-2014. - Almanach Karaimski 3: 223-236.

Pronobis-Gajdzis, Małgorzata. 2015. Zachować dla przyszłości. Sprawozdanie z prac konserwatorsko-restauratorskich prowadzonych przy drukach i rękopisach karaimskich w roku 2015. - Almanach Karaimski 4: 283-287.

Pronobis-Gajdzis, Małgorzata. 2016. Zachować dla przyszłości. Sprawozdanie z prac konserwatorsko-restauratorskich prowadzonych przy dwóch rękopisach karaimskich w roku 2016. - Almanach Karaimski 5: 257-262.

Pritsak, Omeljan. 1959. Das Karaimische. - Deny, J., Grønbech, K., Scheel, H., Togan, Z.V. (red.). Philologiae Turcicae Fundamenta. Tom 1. Wiesbaden: 318-340.

Shapira, Dan. 2003. The Turkic languages and literatures of the East European Karaites. - Polliack, M. (red.): Karaite Judaism. A guide to its history and literary sources. Leiden, Boston: 657-728.

Shapira, Dan. 2013. The Karaim translation of the Book of Nehemia copied in the $17^{\text {th }}$ century's Crimea and printed in 1840/1841 at Gözleve, on the copyist of the manuscript, and some related issues. - Karaite Archives 1: 133-198. 
Sklare, David. 2003. A Guide to Collections of Karaite Manuscripts. - Polliack, M. (red.): Karaite Judaism. A guide to its history and literary sources. Leiden, Boston: 893-924.

Stachowski, Kamil. 2015. Remarks on the phonology of the transitional period of Northwestern Karaim. - Dil Araştırmalan 16: 29-42.

Sulimowicz, Anna. 2008. Kenesa karaimska w Łucku w świetle dokumentów z archiwum gminy. - Bairašauskaitè, T., Kobeckaitè, H., Miškinienė, G. (red.): Orientas Lietuvos Didžiosios Kunigaikštijos visuomenés tradicijoje: totoriai ir karaimai (= Straipsniu rinkinys, parengtas pranešimu, skaitytu tarptautineje mokslo konferencijoje „610-osios totoriu ir karaimu įsikūrimo Lietuvos Didžiojoje Kunigaikštijoje metinès“ 2007 m. rugsëjo 13-15 d. Vilniaus universitete, pagrindu). Vilnius: 2008: 273-281.

Sulimowicz, Anna. 2010. Z dziejów gminy karaimskiej w Łucku. Gminny „dom dochodowy”. - Siemieniec-Gołaś, E., Georgiewa-Okoń, J. (red.): Od Anatolii po Syberię. Swiat turecki w oczach badaczy. Kraków 2010: 199-204.

Sulimowicz, Anna. 2013. Listy do Łucka. Aleksander Mardkowicz jako adresat korespondencji Ananiasza Zajączkowskiego. - Almanach Karaimski 2: 37-60.

Sulimowicz, Anna. 2013. Mieczek i Siunek. - Awazymyz 38/1: 4-13.

Sulimowicz, Anna. 2014. A document on the economic status of the Lutsk Karaites in the mid-19 ${ }^{\text {th }}$ century. - Karaite Archives 2: 177-200.

Sulimowicz, Anna. 2015a. Crimean Karaim manuscripts in the Józef Sulimowicz collection. - Rocznik Orientalistyczny 68/2: 169-179.

Sulimowicz, Anna. 2015b. Działalność społeczna i edukacyjna Koła Pań Karaimskich w Haliczu. - Almanach Karaimski 4: 79-100.

Sulimowicz, Anna. 2015c. Lutsk Karaite manuscripts and documents in the Józef Sulimowicz collection. - Acta Orientalia Academiae Scientiarum Hungaricae 68/2: 175-182.

Sulimowicz, Anna. 2015d. Nieznany przekład Roty na język karaimski. - Almanach Karaimski 4: 101-116.

Sulimowicz, Anna. 2015e. On the Karaite Prayer House in Lutsk and its Furnishings. Bareja-Starzyńska, A., Stanek, K., Godzińska, M., Sulimowicz, A.A., Szpindler, M., Bojarska-Cieślik, J. (red.): Oriental Studies and Arts. Contributions Dedicated to Professor Tadeusz Majda on His 85 ${ }^{\text {th }}$ Birthday. Warszawa: 343-368.

Sulimowicz, Anna. 2016. XIX-wieczny rękopis z polskich archiwów prywatnych zawierający dwa dokumenty dotyczące Karaimów trockich. - Almanach Karaimski 5: 189-205.

Sulimowicz, Józef. 1968. Mistar i halicko-karaimskie surałar. - Roczniki Biblioteczne 1/4: 37-49.

Sulimowicz, Józef. 1972. Materiał leksykalny krymskokaraimskiego zabytku językowego (druk z 1734 r.). - Rocznik Orientalistyczny 35/1: 37-76.

Sulimowicz, Józef. 1973. Materiał leksykalny krymskokaraimskiego zabytku językowego (druk z 1734 r.). II. - Rocznik Orientalistyczny 36/1: 47-107.

Šabarovśkyj, Volodymyr. 2013. Karajimy na Volyni (štrychy do portreta zahadkovoho narodu). Lućk.

Trzciński, Andrzej. 2004. Badania paleograficzne nad pismem hebrajskim średniowiecznym i nowożytnym. - Annales Universitatis Mariae Curie-Skłodowska 2 (sectio L): 61-82. 
Tyszkiewicz, Jan. 2015. Jan Grzegorzewski w końcowych latach życia: 1916-1922. - Almanach Karaimski 4: 117-126.

Vasileva [= Vasilyeva], Olga. 2014. Documents in the Firkovich Collection: Valuable sources on the history of the Jewish communities in Europe and the Middle East from the $12^{\text {th }}$ to the $19^{\text {th }}$ century. - Karaite Archives 2: 201-220.

Walfish, Barry Dov. 2003. Karaite press and printing. - Polliack, M. (red.): Karaite Judaism. A guide to its history and literary sources. Leiden, Boston: 925-959.

Walfish, Barry Dov (we współpracy z: Kizilov, Mikhail). 2011. Bibliographia Karaitica. An annotated bibliography of Karaites and Karaism. Leiden, Boston.

Witkowski, Rafał. 2013. Some remarks on the history of the Karaites in Grand Duchy of Lithuania in the $15^{\text {th }}$ century. - Karaite Archives 1: 211-242.

Witkowski, Rafał. 2014. Los Karaimów podczas II wojny światowej. Kilka uwag historyka. - Almanach Karaimski 3: 159-214.

Witkowski, Rafał. 2015a. Epizod z życia Seraji Szapszała. - Almanach Karaimski 4: 167-172.

Witkowski, Rafał. 2015b. Glossa do karaimskiej sfragistyki. Projekty pieczęci organizacji karaimskich w Polsce przed drugą wojną światową. - Almanach Karaimski 4: 127-144.

Witkowski, Rafał. 2015c. Protokoły z posiedzeń organizacji karaimskich w II Rzeczypospolitej (1924-1928). - Almanach Karaimski 4: 183-215.

Yardeni, Ada. 1997. The Book of Hebrew Script. History, Palaeography, Script Styles, Calligraphy \& Design. Jerusalem.

Zajączkowska-Łopatto, Maria Emilia. 2013. Listy Ananiasza Zajączkowskiego do Jego Ekscelencji Hadży Seraji Chana Szapszała. - Alamanch Karaimski 2: 5-17.

Zajączkowski, Ananjasz. 1932. Przekłady Trenów Jeremiasza w narzeczu trocko-karaimskiem. - Rocznik Orientalistyczny 8: 181-192.

Zajączkowski, Ananiasz. 1934. Przekłady Trenów Jeremiasza w narzeczu trocko-karaimskiem (tekst i słowniczek). - Rocznik Orientalistyczny 10: 158-177.

Zajączkowski, Ananiasz. 1938. Tatarsko-karaimskie piosenki ludowe z Krymu (t. zw. čĭ). -Rocznik Orjentalistyczny 14 (1939 [1938]): 38-65.

Zajączkowski, Ananiasz. 1926. Literatura karaimska. - Myśl Karaimska 3: 7-17.

Zajączkowski, Ananiasz. 1964. Die karaimische Literatur. - Bazin, L., Bombaci, A., Deny, J., Gökbilgin, T., Fahir, İ., Scheel, H. (red.): Philologiae Turcicae Fundamenta. Tom 2. Wiesbaden: 5-10.

Zajączkowski, Włodzimierz. 1965. Ein Bruchstück des hebräisch-karaimischen Wörterbuches. - Ural-Altaische Jahrbücher 36: 429-433.

Zajączkowski, Włodzimierz. 1980. Karaimische Übersetzungen des Alten Testament. - Folia Orientalia 21: 160-161. 


\section{Aneks \\ (przykłady kart katalogowych)}

\section{Osobna pozycja inwentarzowa}

\begin{tabular}{l|l} 
Autor opisu & Michał Németh, Anna Sulimowicz \\
\hline $\begin{array}{l}\text { Numer } \\
\text { inwentarzowy }\end{array}$ & JSul.I.50-6 \\
\hline $\begin{array}{l}\text { Tytuł / } \\
\text { Nazwa }\end{array}$ & $\begin{array}{l}\text { Przekład Księgi Estery na język karaimski oraz zbiór hymnów } \\
\text { religijnych (pijutów) }\end{array}$ \\
\hline $\begin{array}{l}\text { Druk / } \\
\text { Rękopis }\end{array}$ & Rękopis \\
\hline $\begin{array}{l}\text { Obecność kart } \\
\text { rękopiśmiennych }\end{array}$ & Tak \\
\hline $\begin{array}{l}\text { Miejsce wydania / } \\
\text { Miejsce powstania }\end{array}$ & Łuck, zob. Uwagi \\
\hline $\begin{array}{l}\text { Data wydania / } \\
\text { Data powstania }\end{array}$ & ok. 1815, zob. Uwagi \\
\hline Autor & Zob. Informacja o treści \\
\hline $\begin{array}{l}\text { Kłumacz } \\
\text { Wydawca }\end{array}$ & Niepodany \\
\hline
\end{tabular}




\begin{tabular}{|c|c|}
\hline $\begin{array}{l}\text { Informacja } \\
\text { o treści }\end{array}$ & 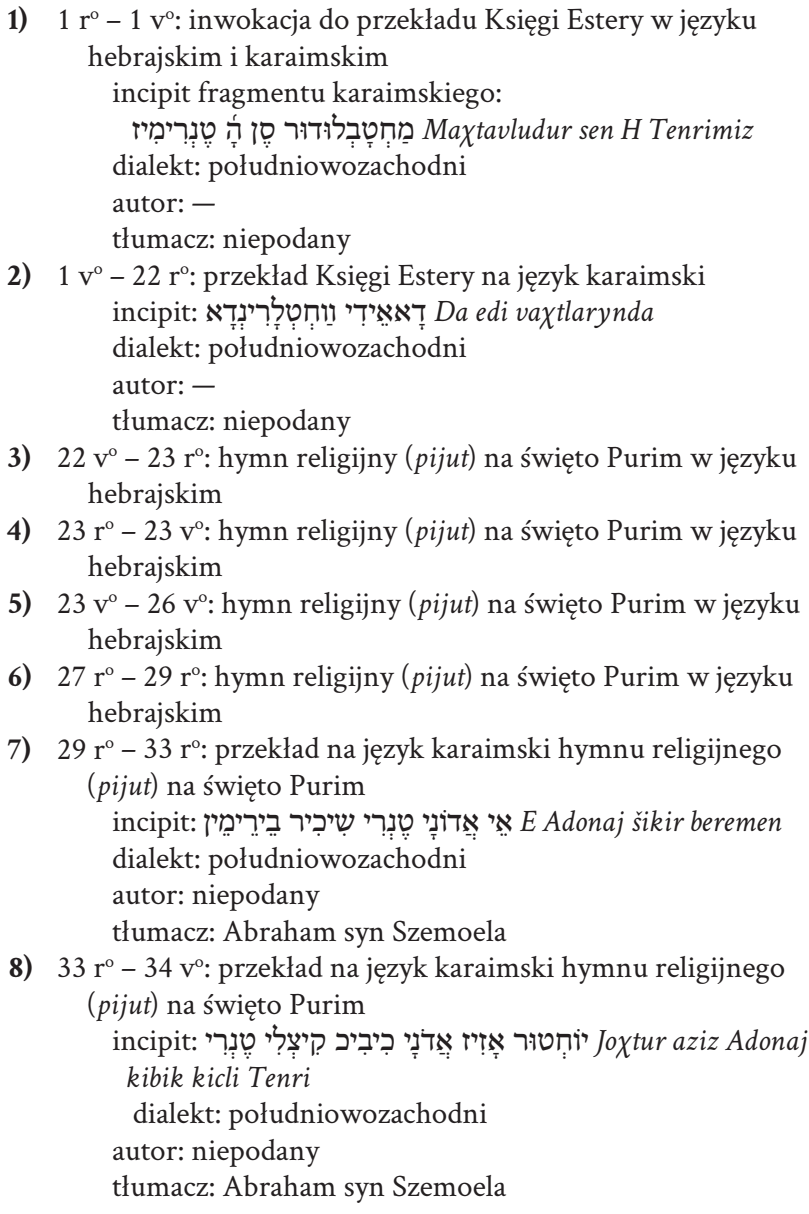 \\
\hline Język & Karaimski, hebrajski \\
\hline Dialekt karaimski & Południowozachodni \\
\hline Glosy & - \\
\hline Rodzaj pisma & Hebrajskie \\
\hline
\end{tabular}




\begin{tabular}{|c|c|c|c|}
\hline Styl pisma & Kwadratowe: - & Półkursywa: Tak & Kursywa: Tak \\
\hline Wokalizacja & \multicolumn{3}{|l|}{ Wokalizowany } \\
\hline Oprawa & \multicolumn{3}{|c|}{ Brak, karty niepozszywane } \\
\hline Papier & \multicolumn{3}{|c|}{$\begin{array}{l}\text { Kremowy, gładki, ślady liniowania rylcem, marginesy zaznaczo- } \\
\text { ne zagięciem papieru, znaki papierni }\end{array}$} \\
\hline Atrament & \multicolumn{3}{|l|}{ Czarny } \\
\hline $\begin{array}{l}\text { Liczba stron / } \\
\text { Liczba kart }\end{array}$ & $36 \mathrm{kk}$. & Numeracja: Brak & \\
\hline Stan zachowania & \multicolumn{3}{|l|}{ Dobry } \\
\hline $\begin{array}{l}\text { Format bloku } \\
(\mathrm{mm})\end{array}$ & \multicolumn{3}{|l|}{-} \\
\hline $\begin{array}{l}\text { Format karty } \\
(\mathrm{mm})\end{array}$ & \multicolumn{3}{|l|}{$180 \times 110$} \\
\hline $\begin{array}{l}\text { Liczba wierszy } \\
\text { na stronę }\end{array}$ & \multicolumn{3}{|l|}{$18-19$} \\
\hline Początek rękopisu & \multicolumn{3}{|l|}{ מגלת אסתר } \\
\hline Koniec rękopisu & \multicolumn{3}{|c|}{ da keneslendi salma goralyn losnun } \\
\hline Uwagi & \multicolumn{3}{|c|}{$\begin{array}{l}\text { Na kk. 7, 16, 25, } 30 \text { wytłoczony znak papierni. Karty 35-36 puste. } \\
\text { Rękopis składa się z } 5 \text { składek niezszytych i nieoprawionych razem. } \\
\text { Na k. } 1 \mathrm{r}^{\circ} \text { adnotacja ręką J. Sulimowicza: } Z \text { Łucka. Na kk. } 29 \mathrm{r}^{\circ}- \\
29 \text { vo nagłówek zawierający datę } 3 \text { dzień miesiąca adar } 5575 \text { A.M. } \\
\text { (tj. } 13 \text { luty 1815). Tłumaczem dwóch hymnów (poz. } 7 \text { i 8) był Abra- } \\
\text { ham syn Szemoela, wymieniony jako osoba żyjąca, teść kopisty. }\end{array}$} \\
\hline
\end{tabular}




\section{Rękopis, druk lub maszynopis jako część pozycji inwentarzowej}

\begin{tabular}{|c|c|}
\hline Autor opisu & Michał Németh \\
\hline $\begin{array}{l}\text { Numer } \\
\text { inwentarzowy }\end{array}$ & ADub.III.90 \\
\hline Tytuł / Nazwa & 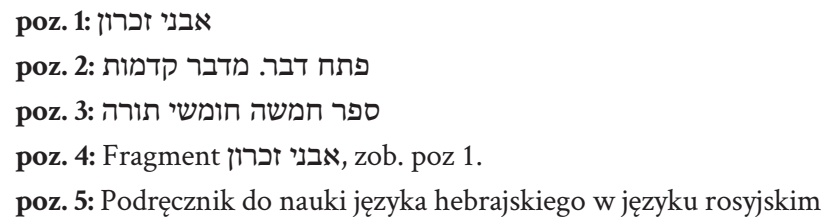 \\
\hline $\begin{array}{l}\text { Numery } \\
\text { inwentarzowe } \\
\text { dokumentów } \\
\text { wchodzących } \\
\text { w skład pozycji }\end{array}$ & $\begin{array}{l}\text { poz. 1: ADub.III.90.1 } \\
\text { poz. 2: ADub.III.90.2 } \\
\text { poz. 3: ADub.III.90.3 } \\
\text { poz. 4: ADub.III.90.4 } \\
\text { poz. 5: ADub.III.90.5 }\end{array}$ \\
\hline $\begin{array}{l}\text { Druk / } \\
\text { Rękopis }\end{array}$ & $\begin{array}{l}\text { poz. 1: Druk } \\
\text { poz. 2: Druk } \\
\text { poz. 3: Druk } \\
\text { poz. 4: Druk } \\
\text { poz. 5: Druk }\end{array}$ \\
\hline $\begin{array}{l}\text { Miejsce wydania / } \\
\text { Miejsce powstania }\end{array}$ & $\begin{array}{l}\text { poz. 1: Wilno } \\
\text { poz. 2: Wilno (?) } \\
\text { poz. 3: Wilno } \\
\text { poz. 4: Wilno } \\
\text { poz. 5: Wilno (?) }\end{array}$ \\
\hline $\begin{array}{l}\text { Data wydania / } \\
\text { Data powstania }\end{array}$ & $\begin{array}{l}\text { poz. 1: } 1872 \\
\text { poz. 2: XIX w. (?) } \\
\text { poz. 3: } 1888 \\
\text { poz. 4: } 1872 \\
\text { poz. } 5 \text { : } \mathrm{XIX} / \mathrm{XX} \text { w. }\end{array}$ \\
\hline
\end{tabular}




\begin{tabular}{|c|c|}
\hline Autor & $\begin{array}{l}\text { poz. 1: Abraham Firkowicz } \\
\text { poz. 2: Niepodany } \\
\text { poz. 3: - } \\
\text { poz. 4: Abraham Firkowicz } \\
\text { poz. 5: Niepodany }\end{array}$ \\
\hline Tłumacz & $\begin{array}{l}\text { poz. 1: - } \\
\text { poz. 2: Zacharja syn Mikaela Mickiewicz, Elijahu syn Joszijahu } \\
\text { Rojecki } \\
\text { poz. } 3: \text { Niepodany } \\
\text { poz. } 4:- \\
\text { poz. } 5:-\end{array}$ \\
\hline Wydawca & $\begin{array}{l}\text { poz. 1: Niepodane } \\
\text { poz. 2: Niepodane } \\
\text { poz. 3: Niepodane } \\
\text { poz. 4: Niepodane } \\
\text { poz. 5: Niepodane }\end{array}$ \\
\hline Drukarnia & $\begin{array}{l}\text { poz. 1: Типографія С.И. Фина и А.Г. Розенкранца } \\
\text { poz. 2: Niepodane } \\
\text { poz. 3: Типографія С.И. Фина и А.Г. Розенкранца } \\
\text { poz. 4: Типографія С.И. Фина и А.Г. Розенкранца } \\
\text { poz. 5: Niepodane }\end{array}$ \\
\hline Kopista & $\begin{array}{l}\text { poz. } 1:- \\
\text { poz. } 2:- \\
\text { poz. } 3:- \\
\text { poz. } 4:- \\
\text { poz. } 5:-\end{array}$ \\
\hline Informacja o treści & $\begin{array}{l}\text { Koperta zawierająca druki: } \\
\text { poz. 1: Opracowanie hebrajskich nagrobków na Krymie } \\
\text { poz. 2: Dzieło historyczne w języku hebrajskim (?) } \\
\text { poz. 3: Przekład Księgi Rodzaju na język karaimski } \\
\text { poz. 4: Fragment opracowania hebrajskich nagrobków na Krymie } \\
\text { poz. 5: Fragment podręcznika do nauki języka hebrajskiego } \\
\text { w języku rosyjskim }\end{array}$ \\
\hline
\end{tabular}




\begin{tabular}{|c|c|}
\hline Język & $\begin{array}{l}\text { poz. 1: Hebrajski } \\
\text { poz. 2: Hebrajski } \\
\text { poz. 3: Karaimski, hebrajski } \\
\text { poz. 4: Hebrajski } \\
\text { poz. } 5 \text { : Rosyjski, hebrajski }\end{array}$ \\
\hline Dialekt karaimski & $\begin{array}{l}\text { poz. 1: - } \\
\text { poz. 2: - } \\
\text { poz. 3: Północnozachodni } \\
\text { poz. 4: - } \\
\text { poz. } 5:-\end{array}$ \\
\hline Glosy & $\begin{array}{l}\text { poz. } 1:- \\
\text { poz. } 2:- \\
\text { poz. } 3:- \\
\text { poz. } 4:- \\
\text { poz. } 5:-\end{array}$ \\
\hline Rodzaj pisma & $\begin{array}{l}\text { poz. 1: Hebrajskie } \\
\text { poz. 2: Hebrajskie } \\
\text { poz. 3: Hebrajskie } \\
\text { poz. 4: Hebrajskie } \\
\text { poz. 5: Hebrajskie }\end{array}$ \\
\hline Styl pisma & $\begin{array}{l}\text { poz. } 1:- \\
\text { poz. } 2:- \\
\text { poz. } 3:- \\
\text { poz. } 4:- \\
\text { poz. } 5:-\end{array}$ \\
\hline Wokalizacja & $\begin{array}{l}\text { poz. 1: Brak } \\
\text { poz. } 2: \mathrm{Brak} \\
\text { poz. } 3: \mathrm{Tak} \\
\text { poz. } 4: \mathrm{Brak} \\
\text { poz. } 5: \mathrm{Tak}\end{array}$ \\
\hline Oprawa & $\begin{array}{l}\text { poz. 1: Zniszczona } \\
\text { poz. 2: Zniszczona } \\
\text { poz. 3: Tekturowa } \\
\text { poz. 4: Zniszczona } \\
\text { poz. } 5 \text { : Zniszczona, zachowana tylko tylna część okładki }\end{array}$ \\
\hline
\end{tabular}




\begin{tabular}{|c|c|}
\hline Papier & $\begin{array}{l}\text { poz. 1: Drukarski } \\
\text { poz. 2: Drukarski } \\
\text { poz. 3: Drukarski } \\
\text { poz. 4: Drukarski } \\
\text { poz. 5: Drukarski }\end{array}$ \\
\hline Atrament & $\begin{array}{l}\text { poz. 1: }- \\
\text { poz. 2: }- \\
\text { poz. 3: }- \\
\text { poz. 4: - } \\
\text { poz. 5: - }\end{array}$ \\
\hline $\begin{array}{l}\text { Liczba stron / } \\
\text { Liczba kart }\end{array}$ & $\begin{array}{l}\text { poz. 1: } 206 \text { str. } \\
\text { poz. 2: } 104 \text { str. } \\
\text { poz. 3: } 64 \text { str. } \\
\text { poz. 4: } 16 \text { str. } \\
\text { poz. 5: } 41 \text { str. }\end{array}$ \\
\hline Numeracja & $\begin{array}{l}\text { poz. 1: Ciągła } \\
\text { poz. 2: Ciągła } \\
\text { poz. 3: Ciągła, strony recto: numeracja hebrajska, strony verso: } \\
\text { numeracja cyframi arabskimi } \\
\text { poz. 4: Ciągła } \\
\text { poz. } 5 \text { : Ciągła, } 14-38,227-282\end{array}$ \\
\hline $\begin{array}{l}\text { Obecność kart } \\
\text { rękopiśmiennych }\end{array}$ & $\begin{array}{l}\text { poz. } 1: \mathrm{Nie} \\
\text { poz. } 2: \mathrm{Nie} \\
\text { poz. } 3: \mathrm{Nie} \\
\text { poz. } 4: \mathrm{Nie} \\
\text { poz. } 5: \mathrm{Nie}\end{array}$ \\
\hline Stan zachowania & $\begin{array}{l}\text { poz. 1: Druk poniszczony } \\
\text { poz. 2: Druk poniszczony } \\
\text { poz. 3: Druk poniszczony } \\
\text { poz. 4: Druk poniszczony } \\
\text { poz. 5: Druk poniszczony }\end{array}$ \\
\hline $\begin{array}{l}\text { Format bloku } \\
(\mathrm{mm})\end{array}$ & $\begin{array}{l}\text { poz. 1: } 240 \times 160 \\
\text { poz. } 2: 240 \times 160 \\
\text { poz. 3: } 240 \times 160 \\
\text { poz. 4: } 240 \times 160 \\
\text { poz. 5: } 245 \times 165\end{array}$ \\
\hline
\end{tabular}




\begin{tabular}{|c|c|}
\hline $\begin{array}{l}\text { Format karty } \\
(\mathrm{mm})\end{array}$ & $\begin{array}{l}\text { poz. } 1: 240 \times 160 \\
\text { poz. } 2: 240 \times 160 \\
\text { poz. 3: } 240 \times 160 \\
\text { poz. 4: } 240 \times 160 \\
\text { poz. 5: } 240 \times 160\end{array}$ \\
\hline $\begin{array}{l}\text { Liczba wierszy } \\
\text { na stronę }\end{array}$ & $\begin{array}{l}\text { poz. } 1:- \\
\text { poz. } 2:- \\
\text { poz. } 3:- \\
\text { poz. } 4:- \\
\text { poz. } 5:-\end{array}$ \\
\hline Początek rękopisu & $\begin{array}{l}\text { poz. } 1:- \\
\text { poz. } 2:- \\
\text { poz. } 3:- \\
\text { poz. } 4:- \\
\text { poz. } 5:-\end{array}$ \\
\hline Koniec rękopisu & $\begin{array}{l}\text { poz. } 1:- \\
\text { poz. } 2:- \\
\text { poz. } 3:- \\
\text { poz. } 4:- \\
\text { poz. } 5:-\end{array}$ \\
\hline Uwagi & $\begin{array}{l}\text { poz. 1: Druk wybrakowany. } \\
\text { poz. 2: - } \\
\text { poz. 3: Właścicielem był Icchak Czaprocki syn Rubena. } \\
\text { poz. 4: Druk wybrakowany. } \\
\text { poz. } 5 \text { : Druk wybrakowany. }\end{array}$ \\
\hline
\end{tabular}


